\title{
PETROLOGICAL CHARACTERIZATION AND REMOTE SENSING-BASED MAPPING OF WADI EL GHUZA AREA, NORTH EASTERN DESERT, EGYPT
}

\author{
El-Gameel, Kh., Eliwa, H. A., Abdelrashid, M. A. and El Desouky, H. A. \\ Geology Department, Faculty of Science, Menoufia University, Egypt \\ ${ }^{*}$ Corresponding author: elgameel2002@yahoo.com
}

\begin{abstract}
Wadi El Ghuza area is located north of Safaga-Qena asphaltic Road and covers an area of about 450 $\mathrm{km}^{2}$, dominated by different Late Neoproterozoic plutonic and volcanic complexes. The area comprises metavolcanics, serpentinites, metagabbros, older Granitoids, volcanosedimentary succession, felsitic intrusions, younger Granites, and post granitic dykes, respectively from the oldest to youngest rock units. Six consecutive sections were measured for the first time on the Wadi El Ghuza volcanosedimentary successions and exhibited stratigraphic intercalation between the Dokhan-type volcanics and the Hammamat sedimentary rocks. A new detailed geological map of the study area was prepared using remote sensing techniques and conventional and unconventional fieldwork. The false color composite 157 in RGB derived from ETM+ data and the composite 421 in RGB derived from ASTER principal component analysis technique discriminated and distinguished the lithology of different rock units in Wadi El Ghuza area. Geochemical studies of the Late Neoproterozoic units including the Dokhan volcanics and the Younger Granites indicate that they are high-K calc-alkaline affinity and were produced from A-type magmas in post-collisional settings. The studied A-type magma has been assumed to be generated by melting of crustal rocks of tonalite composition.
\end{abstract}

Keywords: Wadi El Ghuza, Dokhan Volcanics, Younger Granites, Remote Sensing, Mapping

\section{INTRODUCTION}

The Precambrian basement rocks of the Eastern Desert (ED) of Egypt form an elongate mountainous belt along the western flank of the Red Sea (El-Gaby et al., 1990; Fig. 1). It constitutes the extreme north western part of the Arabian-Nubian Shield (ANS), which extends from Egypt in the west to Saudi Arabia and Oman in the east and from Jordan in the north to Eritrea and Ethiopia in the south. The ANS consists primarily of Neoproterozoic juvenile crust and represents an area of suturing between East and West Gondwana before the Paleozoic (Stern, 1994). It formed through the accretion of numerous, mainly interoceanic, island arcs along ophiolite-lined suture zones and gneissic fault zones between $900 \mathrm{Ma}$ and 550 Ma when the Mozambique ocean closed (Stern, 1994). The Neoproterozoic basement rocks of the ED include gneisses, ophiolitic mélange represented by serpentinites, metagabbro, and metabasalt that were subsequently intruded by volcanics and abundant granitoids, and overlain by molasse-type sediments (Hassan and Hashad, 1990, Stern et al., 2004).

Wadi El Ghuza area is located north of the Safaga-Qena asphaltic road in the North Eastern Desert between Latitudes $26^{\circ} 49^{\prime}$ and $26^{\circ} 56^{\prime} \mathrm{N}$, and Longitudes $33^{\circ} 1^{\prime}$ and $3314^{\prime} \mathrm{E}$ (Fig. 1). It covers an area of about $450 \mathrm{~km}^{2}$ in the northwestern sector of the Safaga Quadrangle Sheet. Variable Neoproterozoic basement rocks with complex field relationships mainly cover the area. The geological setting of these rock units is poorly reported. The present research aims to characterize the geological setting of Wadi El Ghuza area with a special emphasis on the Late Neoproterozoic rocks. Detailed remote sensing investigations were performed and were combined with fieldwork and petrographic investigations to identify the different rock units and to present a new detailed precise geological map. Moreover, detailed stratigraphic relationships for the Late Neoproterozoic volcanosedimentary succession are presented for the first time. Furthermore, new insights on the geochemical aspects and petrogenesis of Late Neoproterozoic rock units including Dokhan-type volcanics and Younger Granites are presented. 
El-Gameel, et al.

Fig. 1: Map showing the distribution of the Precambrian basement rocks in Egypt (El-Gameel, 2018 modified after El-Gaby et al., 1990).

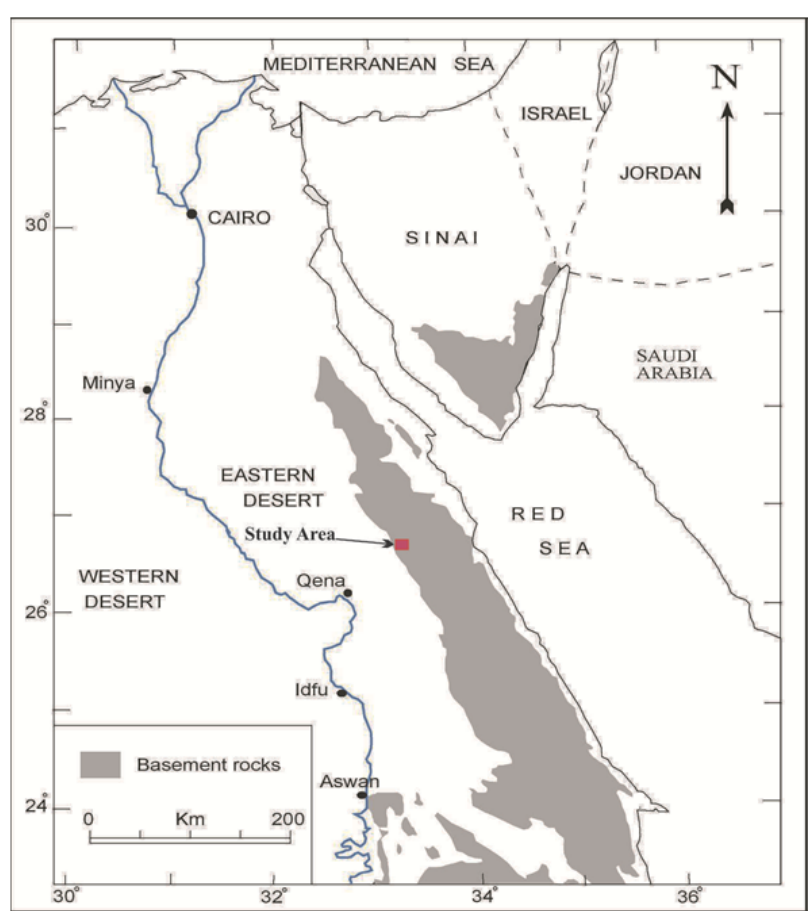

\section{METHODOLOGY}

During the fieldwork, the different rock unites were carefully sampled and their field relationships were investigated. A total of 120 representative hand specimens were collected form the different rock units. Moreover, 6 consecutive lithostratigraphic profiles were measured in detail throughout the Late Neoproterozoic volcanosedimentary successions. 70 representative thin sections were carefully prepared for detailed petrographic examination on the different rock units using a standard polarized microscope. Twenty-five representative samples for the Dokhan-type volcanics and granitic rocks were selected for chemical analysis. The analyses were performed by the standard XRF technique on an instrument operating at the Department of Geology, Tallinn University, Estonia.

For remote sensing-based geological mapping, two cloud-free satellite scenes were used. The first is an Advanced Spaceborne Thermal Emission Reflection Radiometer (ASTER) image acquired in the $1^{\text {st }}$ of June 2004 (path 175, row 41). The second is a Landsat Enhanced Thematic Mapper Plus (ETM+) image acquired in the $19^{\text {th }}$ of October 2000 (path 175, row 41). The two images have different spatial and spectral resolutions. The ASTER image has three spectral bands in the visible-near infrared (VNIR) region, six spectral bands in the shortwave infrared (SWIR) region and five spectral bands in the thermal infrared (TIR) region with $15 \mathrm{~m}, 30 \mathrm{~m}$ and $90 \mathrm{~m}$ spatial resolution, respectively (Amer et al., 2010). The ETM+ image is composed of 8 bands, 6 VNIR and SWIR bands with $30 \mathrm{~m}$ special resolution, 1 TIR band with $60 \mathrm{~m}$ special resolution and 1 panchromatic band with a $15 \mathrm{~m}$ special resolution (Hashim et al., 2013). An image fusion technique was performed to enhance the spatial resolution of the ETM+ image. Spectral resampling has been applied to downscale the spatial resolution of the ASTER image to $15 \mathrm{~m}$ and the ETM+ image to $14.25 \mathrm{~m}$ (Subramanian et al., 2006, Yakhdani and Azizi, 2010). The images were spatially resampled to the dimensions of the study area. Several image enhancement techniques were performed on the ASTER and ETM+ images to identify and map the different rock units in the study area. Image pre-processing and enhancements were performed using the ENVI software. ENVI processed images were inserted as layers in the ArcGIS software. The rock boundaries of the various rock units and structural lineaments were mapped by manual on-screen digitizing to prepare a high-quality detailed geological map (Fig. 2). This map was further verified during fieldwork and the rock unit terminology was confirmed by detailed petrographic investigations. 
Petrological characterization and remote sensing-based mapping

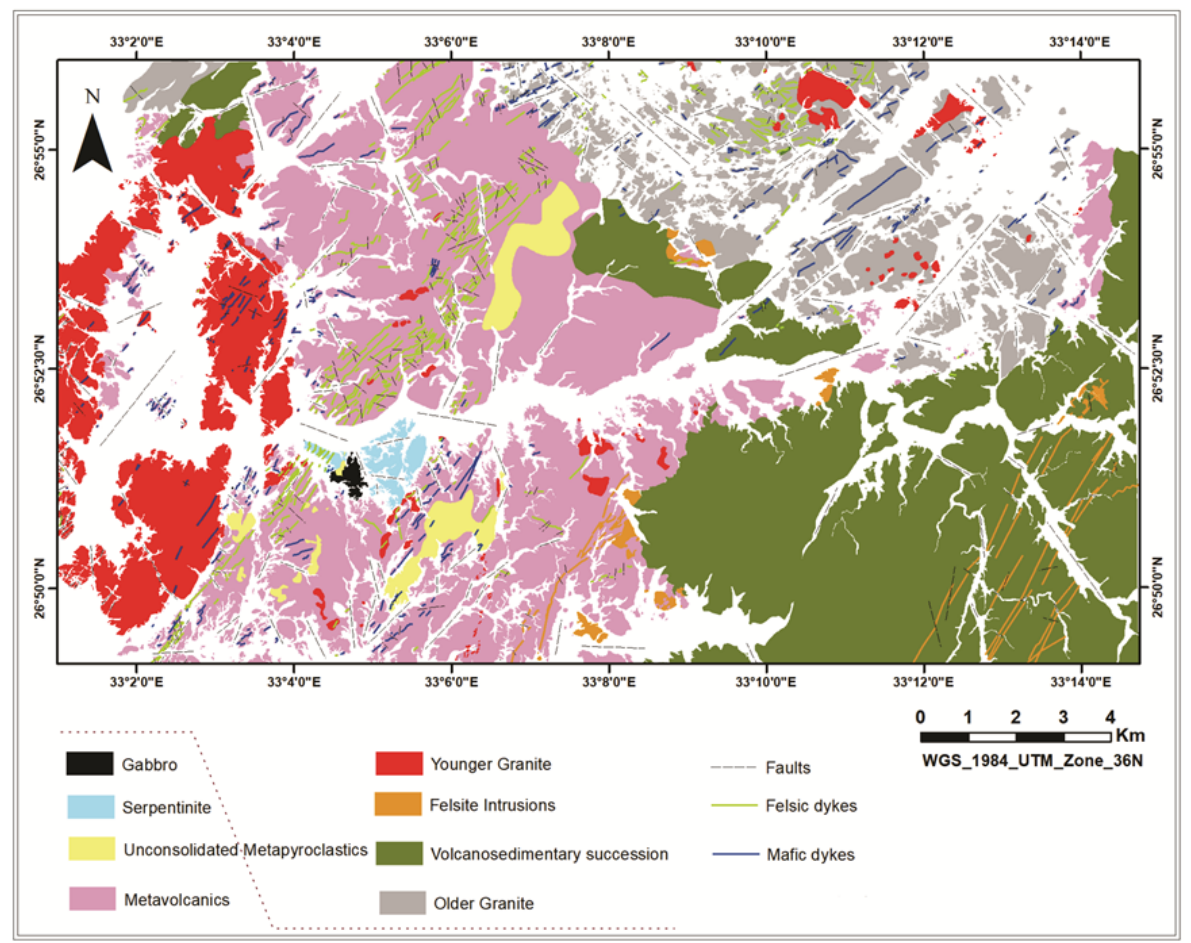

Fig. 2: Geological map of Wadi El Ghuza area prepared from remote sensing and conventional fieldwork.

\section{GEOLOGICAL SETTING}

Field investigations and petrographic examination along with detailed ASTER and ETM+ image processing indicate that the area of Wadi El Ghuza comprises the following main rock units, respectively from older to younger: metavolcanics, serpentinites, gabbros, older granitoids, a volcanosedimentary succession, felsitic intrusions, younger granites, and post-granitic dykes (Fig. 2).

\section{Metavolcanics}

Metavolcanics represent the oldest and the major rock unit cropping out in the area forming continuous low to moderate-relief hilly terrains with moderate slopes. Towards the southern east, metavolcanics have sharp contact with Dokhan volcanics (Fig. 3a), and are intruded by younger granite towards the west. They represent a low-grade regionally metamorphosed old volcanic succession that is highly fractured and jointed in variable directions and showing foliated structure. They are fine-grained rocks exhibiting occasionally aphanitic to porphyritic texture with plagioclase laths and pyroxene phenocrysts. Metaandesites represent the major variety of the exposed metavolcanics, with minor meta-basaltic andesites, meta-dacites and meta-rhyodacites. Most varieties are porphyritic and show a variable ophitic, subophitic and glomeroporphyritic textures.

The mafic metavolcanics are composed of phenocrysts of plagioclase, amphibole (hornblende and tremolite-actinolite), little pyroxene (mainly augite), and few biotite embedded in a finer microcrystalline groundmass of plagioclase, hornblende, tremolite-actinolite, quartz, chlorite, and opaques (Fig. 3b). Sphene and epidote represent the main accessory minerals. The presence of actinolite, chlorite, and opaques indicate low-grade greenschist facies metamorphism. Felsic metavolcanics are characterized by porphyritic textures and composed essentially of potash feldspars, quartz, plagioclase, and biotite porphyroblasts embedded in fine-grained groundmass of the same composition and few chlorites (Fig. 3c).

\section{Serpentinites}

Serpentinites are fine-grained compact rocks with greenish grey to blackish green color. Locally, serpentinites are cracked and friable due to deformation. They show mesh and bastite textures replacing olivine and pyroxene respectively with some very rare relics of these minerals (Fig. 4). They mainly consist of serpentine minerals (antigorite and chrysotile), talc, and chlorite. Veinlets of iron oxides, likely resulted from alteration, locally fill the spaces inside mesh textures. 
Fig. 3: (A) Field panorama showing the contact between metavolcanics (MV) and Wadi El Ghuza volcanosedimentary succession (WGS), photo looking east. (B) Microphotograph showing general view of metabasaltic andesite (cross-polarized light; CPL). (C) Microphotography showing a porphyritic texture in metadacite (CPL).
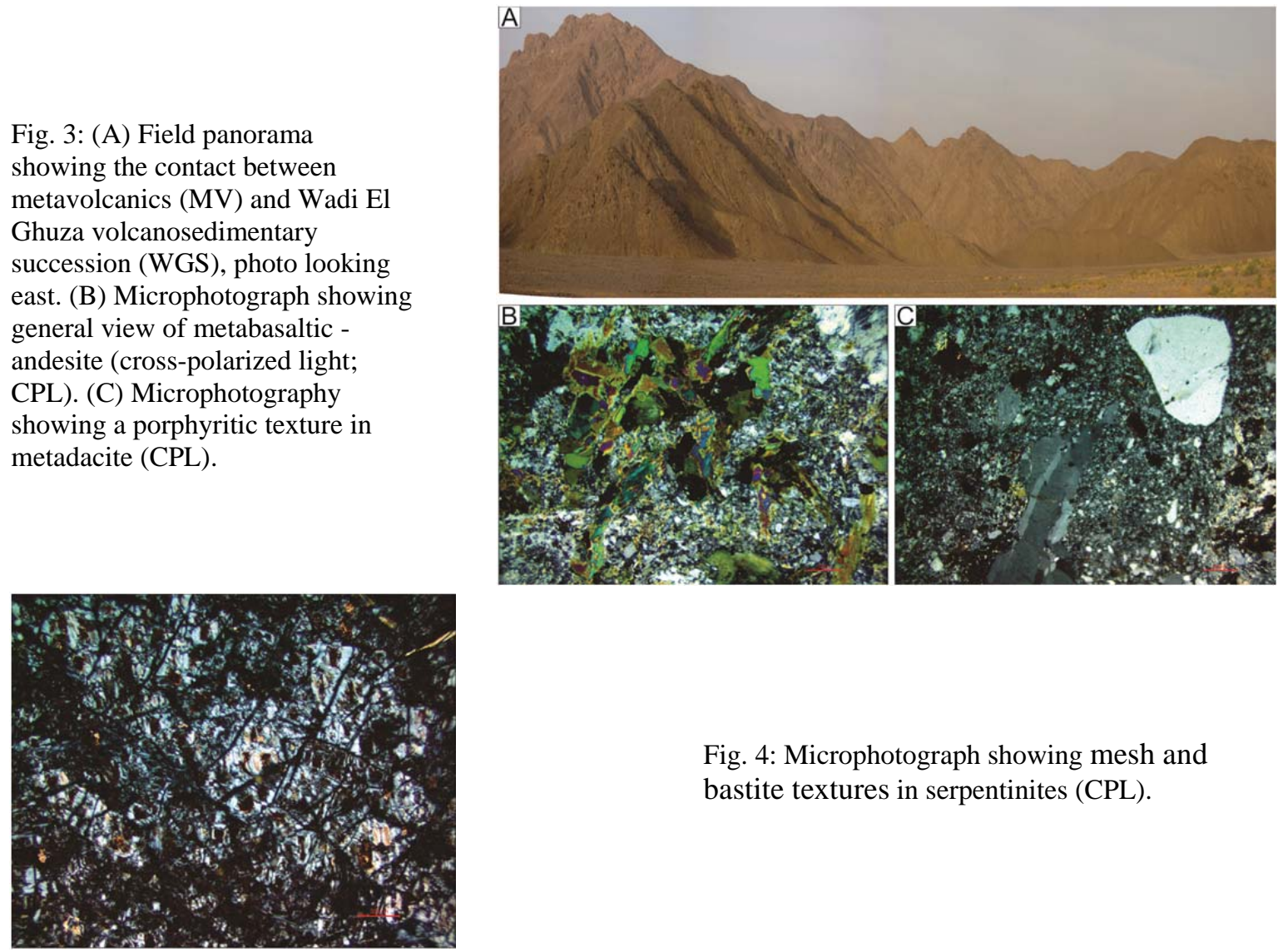

Fig. 4: Microphotograph showing mesh and bastite textures in serpentinites (CPL).

\section{Metagabbros}

Gabbros are melanocratic hard compact medium to coarse-grained rocks. Microscopically, gabbros mainly exhibit allotriomorphic to hypidiomorphic granular textures with some varieties of ophitic, subophitic and corona textures. They are essentially composed of plagioclase, varieties of ortho- and clinopyroxene, hornblende. Iron oxides and epidote occur as the main accessory mineral while chlorite and saussurite are the main secondary minerals.

\section{Older Granitoids}

Older granitoids are mainly exposed in the northeastern part of Wadi El Ghuza area as scattered spheroidal hills with gentle slopes. Towards the west, it intrudes the neighboring metavolcanics with sharp intrusive contacts (Fig. 5a). They are dissected by a series of felsic and mafic dykes with various trends mainly of NE-SW and E-W directions. They range in composition between diorite and granodiorite without remarkable sharp contact. These rocks exhibit seriate inequigranular porphyritic textures (Fig. 5b). Diorite and granodiorite are mainly composed of plagioclase, amphibole, biotite with variable amounts of quartz and k-feldspars. Accessory minerals are apatite, titanite, and opaques with few crystals of zircon. Chlorites along with saussurite are the main secondary minerals.

\section{Volcanosedimentary Succession}

Volcanosedimentary rocks mainly cover the southeastern part of the area. Wadi El Ghuza volcanosedimentary succession (WGS) contains intercalation of two major rock units among the stratigraphic sequence of the basement rocks of Egypt, which are Dokhan volcanics and Hammamat sedimentary rocks (El-Gaby et al., 1990). WGS is approximately $1200 \mathrm{~m}$ thick stratified volcanosedimentary succession that unconformablly overlies metavolcanics with sharp contacts (Fig. 3a). WGS form high rugged mountains with sharp serrated edges and steep slopes intruded by late subvolcanic traverse extended sub-parallel swarm-like felsite intrusions. 
Petrological characterization and remote sensing-based mapping

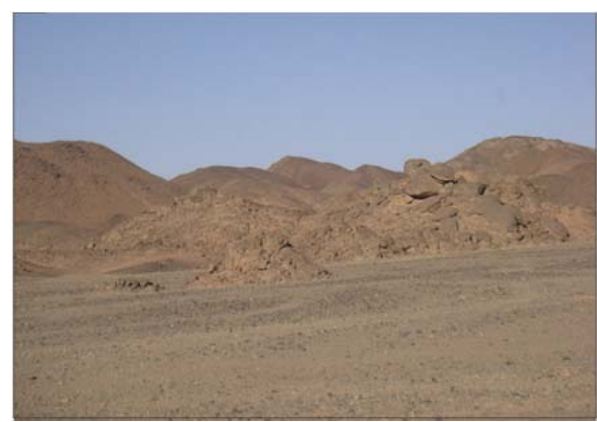

A

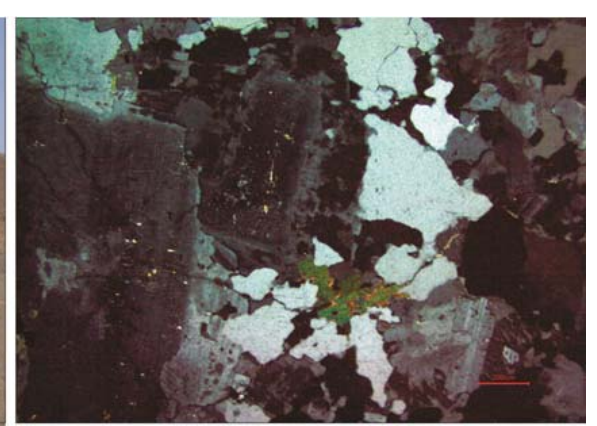

B
Fig. 5: A. Field photograph showing the contact of older granite with metavolcanics, photo looking west. B. Microphotograph showing an inequigranular texture in granodiorite (CPL).

Hammamat sedimentary rocks in WGS, comprises variable sandstones, siltstones, and conglomerates with occasionally occurring thin laminae of clay stone. Sandstones are composed of sandy to silty-sized varieties of arenites and wackes. They are hard massive, fine to coarse-grained rocks exhibit grey and greyish reddish brown colors owing to the color of feldspars and iron oxides. They are composed of quartz, feldspar and little or no lithic fragments embedded in a fine-grained matrix that contains detrital mica (Fig. 6a). Siltstones with pinkish and grey colors occur alternatively with sandstone layers. They are composed of silt to clay-sized sub angular minutes of quartz, feldspar embedded in a finer matrix of feldspars, carbonate, clay, and iron oxides. Conglomerate is characterized by its polymictic character and occurs in an $85 \mathrm{~m}$ thick sequence in the whole succession (Fig. 6b).

The Dokhan volcanics in WGS comprise mainly volcaniclastic mass flow deposits, pyroclastic as well as sub-volcanic bodies of dacitic and rhyolitic composition. The pyroclastic include ignimbrites and fine ash tuff. Pyroclastics represent a distinctive rock variety for the WGS Dokhan volcanics. They show very hard massive nature with variable colors ranging between greyish brown to reddish brown and reddish violet. Pyroclastics show a main primary porphyritic texture that is mainly composed of crystals and crystal fragments, lithics and lithic fragments that are set in a matrix rich in crystal, glass particles, and lithic fragments along with some alteration products such as clay and carbonate (Figs. 6c and d).

Fig. 6: (A) Microphotograph showing general view of moderately sorted arkose arenite (CPL). (B) Field photograph showing conglomerate and its different clast size, photo looking west. (C) Field photograph showing fiamme in ignimbrite, photo looking northeast. (D) Microphotograph photo showing porphyritic texture in ignimbrite (CPL).
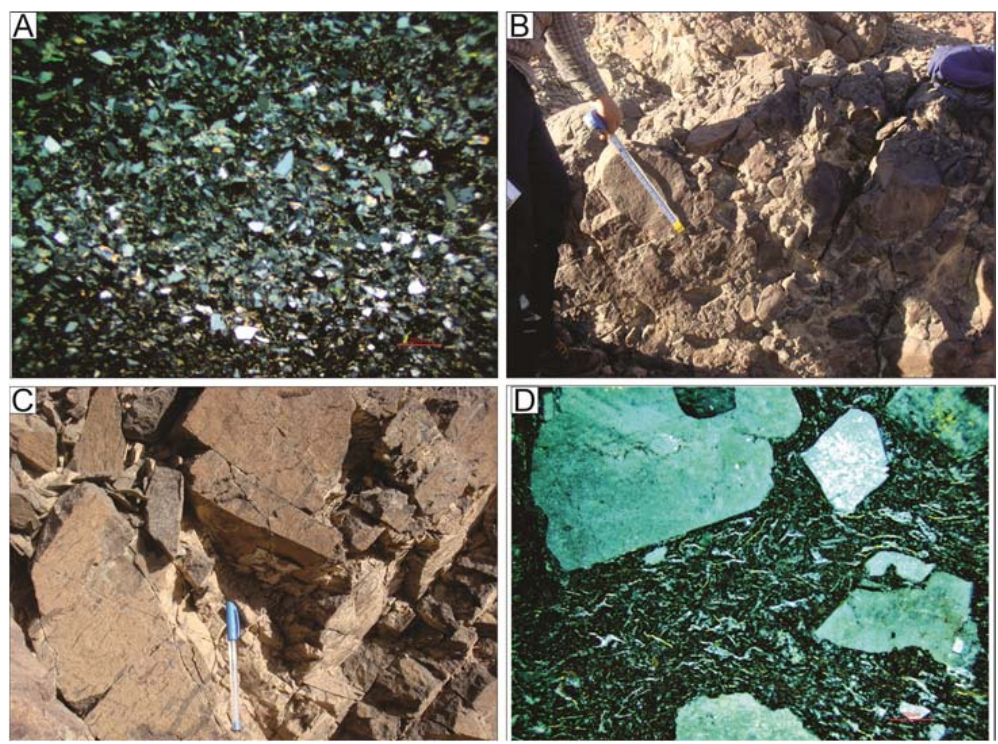

Agglomerates are coarse-grained massive rock with variable buff, greyish brown, brownish grey colors. They are characterized by abundant lithic fragments and lack of pumice fragments and welding. Their main texture is porphyritic where lithics and minor crystal fragments are embedded in a finer matrix rich with microcrystalline feldspar crystal fragments feldspars, quartz and lithics. The WGS beds generally dip towards the North. Six consecutive vertical lithostratigraphic profiles have been measured normal to the general strike of the whole succession and were correlated by marker beds. The measured profiles were combined together to create a general lithostratigraphic profile showing the complete stratigraphic sequence of Wadi El Ghuza volcanosedimentary succession (Fig. 7). 
El-Gameel, et al.

Fig. 7: Generalized lithostratigraphic profile of Wadi El Ghuza volcanosedimentary succession (WGS).

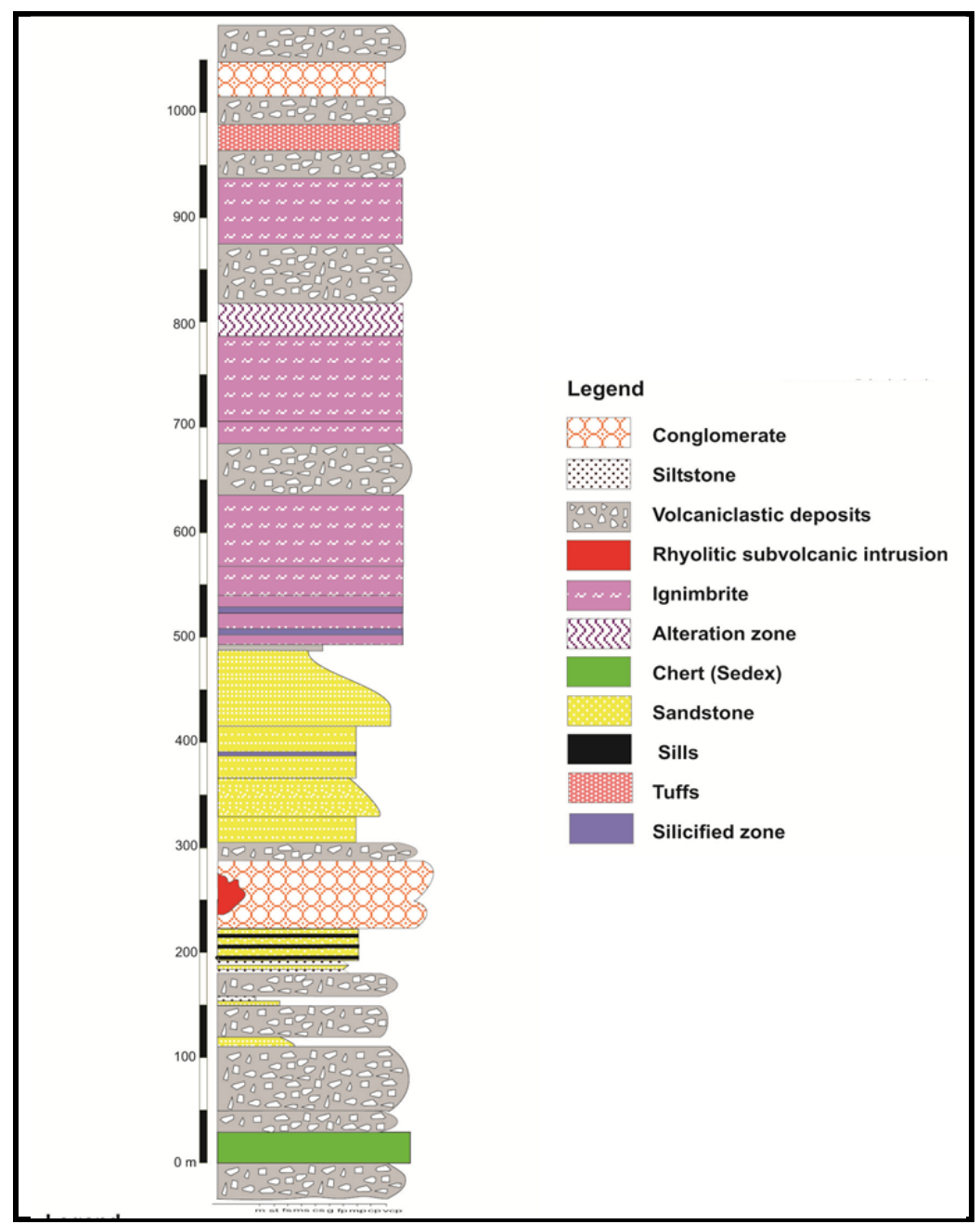

\section{Felsite Intrusions}

Felsite occurs as intrusion bodies, sheets, and plugs in small outcrops allover the basement exposures in Wadi El Ghuza area. Commonly in the southeastern part of the area, they occur as a series of intrusions dissecting the whole volcanosedimentary succession with well-defined sharp contacts and with some noticeable alteration along contacts (Fig. 8a). These intrusions occur as small isolated low relief verifying their character of being sub-volcanic intrusions. The felsite intrusions are reddish brown in color, mediumto fine-grained and characterized by porphyritic textures. They range from rhyolite to rhyodacite porphyry with distinctive porphyritic textures (Fig. 8b). They are mainly composed of plagioclase, quartz, potash feldspar and biotite phenocrysts embedded in a fine groundmass of the same compositions with subordinate amount of calcite.

\section{Younger Granites}

Younger granite rocks totally cover the western side of the study area representing almost 35\% of the exposed rocks in Wadi El Ghuza. Younger granites occur as moderate to high relief, highly peaked with quietly steep slopes huge circular and oval batholiths arranged in two belts separated from each other by Wadi El Atrash. The eastern belt of the younger granites intrudes the surrounding metavolcanics with sharp intrusive contacts (Fig. 8c). They are dissected by several mafic dykes and quartz veins mainly with a NE-SW trend. These rocks are medium to coarsegrained with a characteristic red color and grade in composition from monzogranite to syenogranite with no sharp boundary. Younger granites are composed microscopically of plagioclase, potash feldspars and quartz with variable amounts of biotite and muscovite. Iron oxides, zircon, sphene, and apatite are accessory minerals where saussurite and chlorite are the main secondary minerals. Younger granite exhibit mainly a hypidiomorphic texture with a wide variety of perthites, such as flame, rod (Fig. 8d), patchy, and herringbone perthites. 
Petrological characterization and remote sensing-based mapping
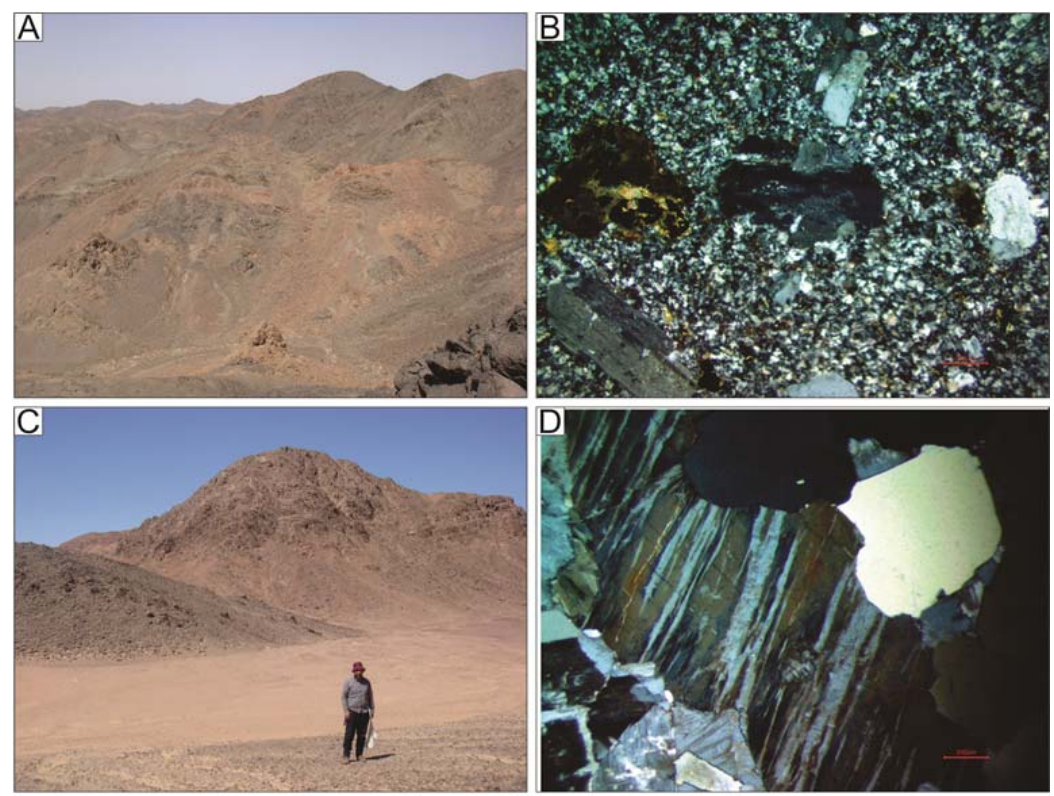

Fig. 8: (A) Field photograph showing felsite intrusions dissecting Wadi El Ghuza succession, photo looking north. (B) Microphotograph showing porphyritic texture of rhyodacite (CPL). (C) Field photograph showing the contact between young granite and metavolcanics, photo looking west. (D) Microphotograph showing welldeveloped rod perthite in syenogranite (CPL).

\section{LITHOLOGICAL MAPPING}

A new detailed geological map of the study area was prepared from remote sensing and conventional fieldwork. For lithological mapping, several image processing techniques were applied on the ASTER and ETM+ images, including, the false color composites (FCC), optimum index factor (OIF; Chavez et al., 1982; Chavez, 1984) and principal component analysis (PCA) techniques (Loughlin, 1991; Yamaguchi and Naito, 2003; Gomez et al., 2005; Sabins, 2007).

The OIF technique was performed in the ETM+ bands to select the best FCC combination for lithological discrimination in the study area. Results allowed identifying a new FCC (157 in RGB; Fig. 9a), with good lithological discrimination from the ETM+ data. In this FCC (Fig. 9a), the different rock units in Wadi El Ghuza area appears with the following colors: aqueous blue for younger granites, crinkled reddish brown for older granites, blue for metavolcanics, purple for serpentinites, deep green for exposed Dokhan volcanics, reddish brown for exposed Hammamat sedimentary rocks and dotted reddish brown color for metapyroclastics.

The PCA module was performed on the 9 VNIR and SWIR bands of the ASTER image in a 9 by 9 covariance matrix and several color composite images were prepared from the new PCA components. Results reveal that the best PCA composite for lithological discrimination in the study area is 421 in RGB (Fig. 9b). In this processed image, the different lithologies in the study area appear with the following colors: magenta for felsic metavolcanics, dark green for mafic metavolcanics, dark blue for serpentinites, reddish yellow for exposed Dokhan volcanics, green for exposed Hammamat sedimentary rocks, and crinkled deep green color for older granites (Fig. 9b).

\section{GEOCHEMISTRY}

Data for chemical composition of representative samples are reported in Table 1 . The selected samples include Dokhan-type volcanics (15 samples of which 11 ignimbrites, 3 agglomerate, 1 tuff, and 1 coherent volcanic), subvolcanic acidic intrusions (3 samples of felsite), and Younger granites (6 samples).

The total alkalis versus silica diagrams (TAS) are important to classify the volcanic and plutonic rocks. Using TAS variation diagram (Le Bas et al., 1986) indicates that the Dokhan-type varieties plot mostly within rhyolite field with minor samples plot within the trachydacite field (Fig. 10a).

On the $\mathrm{SiO}_{2}$ vs. $\left(\mathrm{Na}_{2} \mathrm{O}+\mathrm{K}_{2} \mathrm{O}\right)$ variation diagram (Cox et al., 1979), all the Younger Granite samples plot in the granite-related field except one sample, which plots in the syenite field (Fig. 10b). The enrichment of alkalis is clear in the studied samples, so it could place them in an unexpected compositional field. Therefore, there was an urgent need for another classification based on immobile trace element. 
El-Gameel, et al.

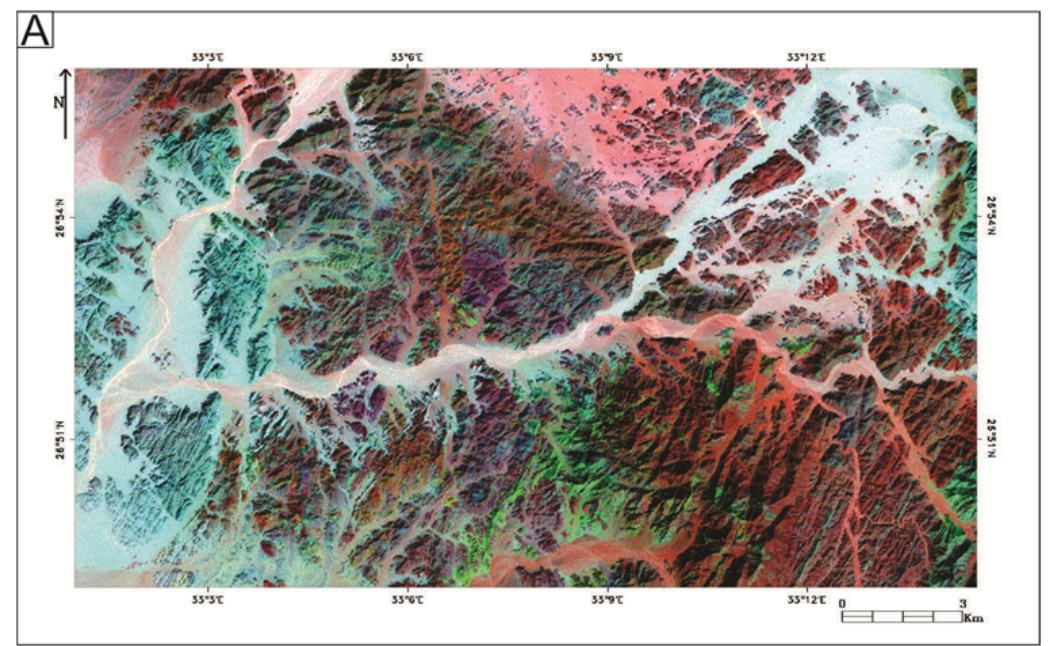

Fig. 9: (A) False color composite of 157 in RGB derived by applying the optimum index factor on ETM+ data. (B) ASTER principal component analysis composite of 421 in RGB.

B
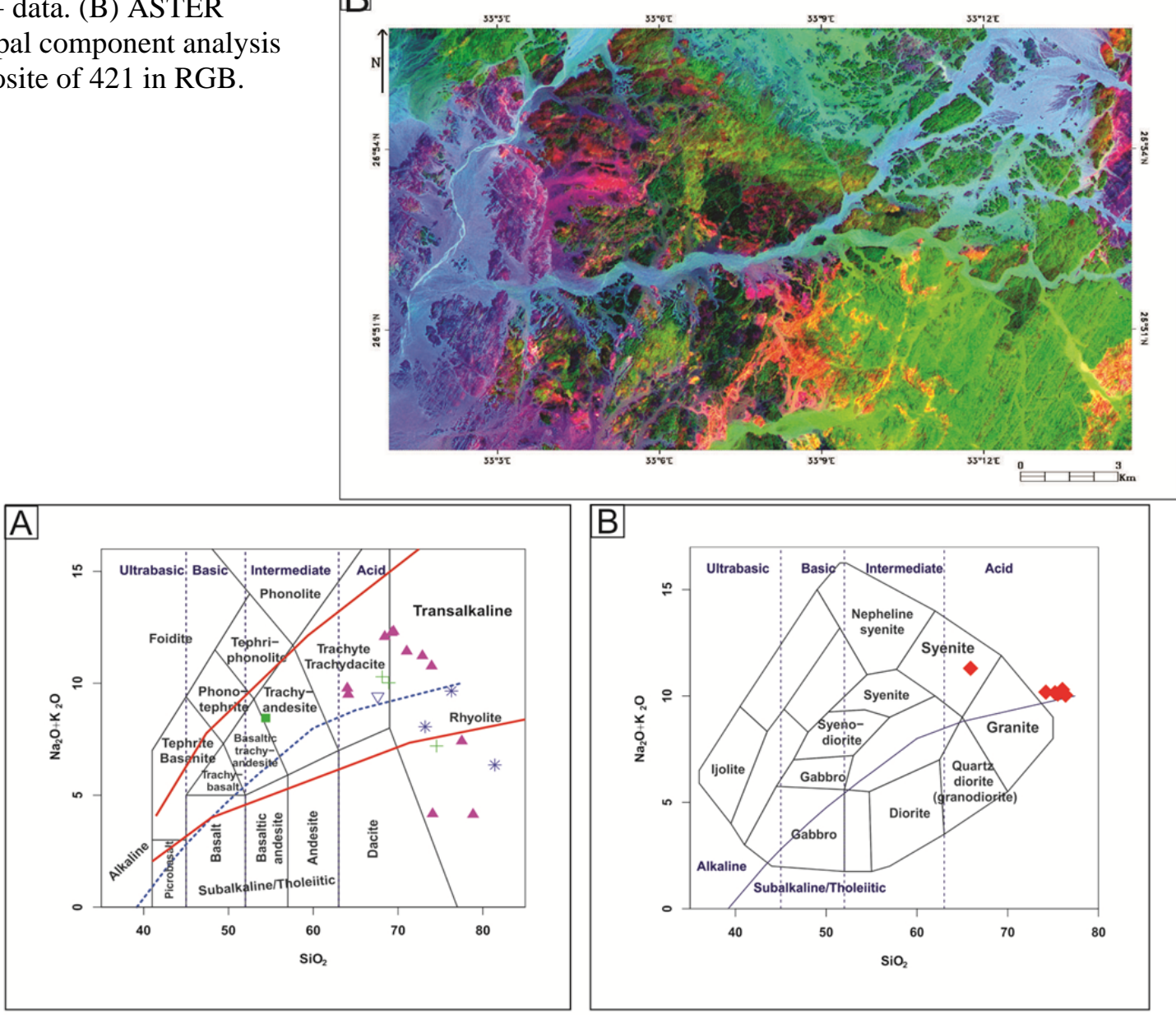

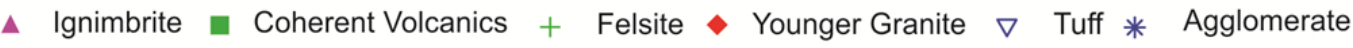

Fig. 10: (A) Total $\mathrm{Na}_{2} \mathrm{O}+\mathrm{K}_{2} \mathrm{O}$ vs. $\mathrm{SiO}_{2}$ TAS diagram for volcanic rocks. The dashed line is the Irvine and Baragar (1971) divider between alkaline and subalkaline rocks, whereas the solid lines are the Middlemost's dividers between alkaline, transalkaline and subalkaline fields (Middlemost, 2014). (B) TAS diagram for the plutonic rocks. 
Table 1: Major oxides (in wt. \%) and trace elements (in ppm) for selected volcanic and granite samples.

\begin{tabular}{|c|c|c|c|c|c|c|c|c|c|c|c|c|c|c|c|c|}
\hline \multirow{3}{*}{\begin{tabular}{|l|} 
Rock Unit \\
Rock Type \\
Sample No. \\
\end{tabular}} & \multicolumn{16}{|c|}{ Dokhan Volcanics } \\
\hline & \multicolumn{11}{|c|}{ Ignimbrite } & \multicolumn{3}{|c|}{ Agglomerates } & \multirow{2}{*}{$\begin{array}{c}\text { Tuff } \\
\text { MR-108 }\end{array}$} & \multirow{2}{*}{$\begin{array}{c}\text { Coherent } \\
\text { MR-89 }\end{array}$} \\
\hline & MR-87 & MR-88 & MR-90 & MR-91-B & MR-94 & MR-96-B & MR-96-C & MR-101 & MR-103 & MR-104 & MR-114 & MR-42 & MR-43 & MR-45 & & \\
\hline $\mathrm{SiO}_{2}$ & 76.74 & 61.71 & 70.76 & 60.65 & 73.34 & 70.38 & 68.60 & 76.37 & 67.78 & 68.91 & 72.31 & 80.13 & 75.61 & 70.22 & 66.57 & 52.46 \\
\hline $\mathrm{Al}_{2} \mathrm{O}_{3}$ & 12.66 & 14.92 & 15.25 & 14.27 & 13.04 & 14.16 & 14.97 & 11.57 & 15.39 & 14.51 & 13.71 & 10.76 & 12.09 & 12.63 & 15.88 & 15.16 \\
\hline $\mathrm{TiO}_{2}$ & 0.216 & 0.861 & 0.949 & 0.897 & 0.291 & 0.443 & 0.391 & 0.192 & 0.505 & 0.429 & 0.273 & 0.130 & 0.268 & 0.206 & 0.573 & 1.776 \\
\hline $\mathrm{Fe}_{2} \mathrm{O}_{3}$ & 3.21 & 4.52 & 2.90 & 4.47 & 1.41 & 1.93 & 2.06 & 2.75 & 2.40 & 2.26 & 1.43 & 0.81 & 1.26 & 1.31 & 3.64 & 8.24 \\
\hline $\mathrm{MnO}$ & 0.020 & 0.059 & 0.003 & 0.080 & 0.042 & 0.069 & 0.079 & 0.018 & 0.050 & 0.067 & 0.025 & 0.019 & 0.013 & 0.291 & 0.071 & 0.104 \\
\hline $\mathrm{CaO}$ & 0.06 & 2.33 & 0.83 & 3.20 & 0.21 & 0.40 & 0.41 & 0.08 & 0.51 & 0.57 & 0.18 & 0.11 & 0.08 & 3.21 & 0.91 & 5.76 \\
\hline $\mathrm{MgO}$ & 0.34 & 2.26 & 0.52 & 1.71 & 0.12 & 0.27 & 0.29 & 0.22 & 0.29 & 0.11 & 0.13 & 0.20 & 0.19 & 0.32 & 1.40 & 4.08 \\
\hline $\mathrm{Na}_{2} \mathrm{O}$ & 0.20 & 5.43 & 0.17 & 5.37 & 5.43 & 6.27 & 6.68 & 3.32 & 7.45 & 7.59 & 5.61 & 3.50 & 5.65 & 1.97 & 4.94 & 5.37 \\
\hline $\mathrm{K}_{2} \mathrm{O}$ & 3.83 & 4.00 & 3.81 & 3.62 & 5.25 & 5.06 & 5.47 & 3.99 & 4.52 & 4.63 & 5.53 & 2.75 & 3.92 & 5.76 & 4.33 & 2.78 \\
\hline $\mathrm{P}_{2} \mathrm{O}_{5}$ & 0.048 & 0.314 & 0.332 & 0.314 & 0.028 & 0.109 & 0.099 & 0.011 & 0.144 & 0.119 & 0.028 & 0.011 & 0.020 & 0.011 & 0.143 & 0.716 \\
\hline LOI & 2.59 & 3.58 & 4.51 & 5.63 & 0.60 & 0.70 & 0.73 & 1.20 & 0.77 & 0.59 & 0.56 & 1.45 & 0.71 & 4.10 & 1.40 & 3.40 \\
\hline Total & 99.91 & 99.98 & 100.03 & 100.21 & 99.76 & 99.79 & 99.78 & 99.72 & 99.81 & 99.79 & 99.79 & 99.87 & 99.81 & 100.03 & 99.86 & 99.85 \\
\hline $\mathrm{Ba}$ & 1594 & 822 & 547 & 872 & 768 & 1060 & 1382 & 542 & 1153 & 1516 & 508 & 132 & 258 & 313 & 431 & 1399 \\
\hline $\mathrm{Sr}$ & 121 & 528 & 192 & 568 & 58 & 287 & 191 & 38 & 184 & 107 & 69 & 52 & 72 & 123 & 257 & 854 \\
\hline $\mathrm{Rb}$ & 71 & 82 & 86 & 89 & 88 & 96 & 99 & 57 & 82 & 65 & 92 & 47 & 107 & 150 & 111 & 59 \\
\hline $\mathrm{Hf}$ & 5.1 & 4.8 & 9.7 & 3.9 & 5.8 & 8.3 & 6.1 & 8.4 & 5.9 & 6.6 & 7.1 & 1.34 & 1.8 & 2.1 & 9.1 & 2.9 \\
\hline Ga & 19 & 20 & 20 & 16 & 16 & 23 & 21 & 21 & 25 & 20 & 16 & 9 & 16 & 23 & 22 & 20 \\
\hline $\mathrm{Cr}$ & 20 & 45 & 72 & 58 & 56 & 23 & 36 & 5 & 19 & 55 & 53 & 15 & 41 & 37 & 27 & 55 \\
\hline $\mathrm{Ni}$ & 14 & 36 & 26 & 29 & 21 & 27 & 22 & 22 & 21 & 24 & 22 & 14 & 19 & 13 & 17 & 34 \\
\hline $\mathrm{Zr}$ & 468 & 222 & 191 & 256 & 248 & 407 & 441 & 555 & 541 & 517 & 230 & 39 & 154 & 85 & 257 & 233 \\
\hline $\mathrm{Nb}$ & 29 & 13 & 10 & 8 & 16 & 13 & 16 & 28 & 16 & 14 & 18 & 13 & 20 & 23 & 27 & 15 \\
\hline $\mathrm{Y}$ & 38 & 30 & 31 & 33 & 27 & 32 & 27 & 20 & 28 & 39 & 34 & 70 & 70 & 68 & 60 & 27 \\
\hline $\mathrm{Cu}$ & 19 & 43 & 28 & 20 & 7 & 5 & 6 & 6 & 6 & 7 & 7 & 10 & 7 & 20 & 15 & 32 \\
\hline $\mathrm{Zn}$ & 51 & 78 & 24 & 55 & 32 & 45 & 49 & 75 & 48 & 31 & 40 & 22 & 34 & 57 & 92 & 104 \\
\hline $\mathrm{Pb}$ & $<10$ & 19 & $<10$ & 17 & $<10$ & 16 & 16 & 22 & 29 & $<10$ & $<10$ & $<10$ & $<10$ & 20 & 20 & $<10$ \\
\hline Th & $<10$ & $<10$ & 13 & $<10$ & $<10$ & $<10$ & $<10$ & $<10$ & 13 & $<10$ & $<10$ & $<10$ & 15 & 18 & $<10$ & $<10$ \\
\hline $\mathrm{U}$ & $<10$ & $<10$ & $<10$ & $<10$ & $<10$ & $<10$ & $<10$ & $<10$ & $<10$ & $<10$ & $<10$ & $<10$ & $<10$ & $<10$ & $<10$ & $<10$ \\
\hline $\mathrm{K} / \mathrm{Rb}$ & 448 & 406 & 368 & 338 & 496 & 438 & 459 & 582 & 458 & 592 & 500 & 486 & 305 & 319 & 324 & 392 \\
\hline $\mathrm{Rb} / \mathrm{Sr}$ & 0.59 & 0.16 & 0.45 & 0.16 & 1.52 & 0.33 & 0.52 & 1.50 & 0.45 & 0.61 & 1.33 & 0.90 & 1.49 & 1.22 & 0.43 & 0.07 \\
\hline $\mathrm{Mg}^{\#}$ & 10.5 & 35.7 & 16.6 & 29.8 & 8.6 & 13.5 & 13.5 & 8.2 & 11.8 & 5.1 & 9.2 & 21.5 & 14.4 & 21.4 & 29.9 & 35.5 \\
\hline $\mathrm{FeO}^{*} / \mathrm{MgO}$ & 8.5 & 1.8 & 5.0 & 2.4 & 10.6 & 6.4 & 6.4 & 11.2 & 7.4 & 18.5 & 9.9 & 3.6 & 6.0 & 3.7 & 2.3 & 1.8 \\
\hline $\mathrm{K}_{2} \mathrm{O} / \mathrm{Na}_{2} \mathrm{O}$ & 19.2 & 0.7 & 22.4 & 0.7 & 1.0 & 0.8 & 0.8 & 1.2 & 0.6 & 0.6 & 1.0 & 0.8 & 0.7 & 2.9 & 0.9 & 0.5 \\
\hline $\mathrm{CaO} / \mathrm{Na}_{2} \mathrm{O}$ & 0.3 & 0.4 & 4.9 & 0.6 & 0.0 & 0.1 & 0.1 & 0.0 & 0.1 & 0.1 & 0.0 & 0.0 & 0.0 & 1.6 & 0.2 & 1.1 \\
\hline $\mathrm{Na}_{2} \mathrm{O}+\mathrm{K}_{2} \mathrm{O}$ & 4.0 & 9.4 & 4.0 & 9.0 & 10.7 & 11.3 & 12.2 & 7.3 & 12.0 & 12.2 & 11.1 & 6.3 & 9.6 & 7.7 & 9.3 & 8.2 \\
\hline $\mathrm{Al}_{2} \mathrm{O}_{3}+\mathrm{CaO}$ & 12.7 & 17.3 & 16.1 & 17.5 & 13.3 & 14.6 & 15.4 & 11.7 & 15.9 & 15.1 & 13.9 & 10.9 & 12.2 & 15.8 & 16.8 & 20.9 \\
\hline $\mathrm{T}_{\mathrm{Zr}}\left({ }^{\circ} \mathrm{C}\right)$ & 977 & 770 & 871 & 767 & 803 & 840 & 842 & 928 & 860 & 844 & 796 & 695 & 768 & 710 & 824 & 710 \\
\hline $\mathrm{T}_{\text {ap }}\left({ }^{\circ} \mathrm{C}\right)$ & 899 & 943 & 1047 & 930 & 821 & 917 & 889 & 778 & 919 & 911 & 811 & 811 & 816 & 718 & 906 & 937 \\
\hline
\end{tabular}


Table 1: Continued.

\begin{tabular}{|c|c|c|c|c|c|c|c|c|c|}
\hline \multirow{2}{*}{$\begin{array}{l}\text { Rock Unit } \\
\text { Rock Type }\end{array}$} & \multicolumn{3}{|c|}{ Subvolcanic Intrusion } & \multicolumn{6}{|c|}{ Younger Granites } \\
\hline & \multicolumn{3}{|c|}{ Felsites } & \multicolumn{6}{|c|}{ Granites } \\
\hline Sample No. & MR-61 & MR-65 & MR-84 & MR-1 & MR-5 & MR-15 & MR-17 & MR-63 & MR-115 \\
\hline $\mathrm{SiO}_{2}$ & 67.53 & 68.28 & 72.89 & 75.22 & 74.21 & 76.38 & 76.03 & 65.91 & 75.52 \\
\hline $\mathrm{Al}_{2} \mathrm{O}_{3}$ & 14.89 & 14.79 & 14.65 & 12.25 & 12.81 & 12.17 & 12.25 & 15.73 & 12.29 \\
\hline $\mathrm{TiO}_{2}$ & 0.538 & 0.531 & 0.354 & 0.170 & 0.215 & 0.125 & 0.114 & 0.582 & 0.140 \\
\hline $\mathrm{Fe}_{2} \mathrm{O}_{3}$ & 2.87 & 2.69 & 2.02 & 0.84 & 0.99 & 0.32 & 0.28 & 2.88 & 0.62 \\
\hline $\mathrm{MnO}$ & 0.066 & 0.064 & 0.026 & 0.018 & 0.011 & 0.002 & 0.006 & 0.084 & 0.032 \\
\hline $\mathrm{CaO}$ & 1.96 & 1.81 & 0.41 & 0.49 & 0.29 & 0.22 & 0.33 & 1.88 & 0.49 \\
\hline $\mathrm{MgO}$ & 0.93 & 0.88 & 0.31 & 0.18 & 0.15 & 0.09 & 0.06 & 0.85 & 0.06 \\
\hline $\mathrm{Na}_{2} \mathrm{O}$ & 6.84 & 6.62 & 4.51 & 5.54 & 5.82 & 5.45 & 5.74 & 8.06 & 5.48 \\
\hline $\mathrm{K}_{2} \mathrm{O}$ & 3.36 & 3.31 & 2.53 & 4.61 & 4.36 & 4.59 & 4.56 & 3.24 & 4.61 \\
\hline $\mathrm{P}_{2} \mathrm{O}_{5}$ & 0.129 & 0.118 & 0.083 & 0.015 & 0.039 & 0.006 & 0.008 & 0.132 & 0.005 \\
\hline LOI & 0.69 & 0.73 & 2.13 & 0.43 & 0.76 & 0.43 & 0.44 & 0.44 & 0.55 \\
\hline Total & 99.80 & 99.82 & 99.91 & 99.76 & 99.66 & 99.78 & 99.82 & 99.79 & 99.80 \\
\hline $\mathrm{Ba}$ & 764 & 785 & 392 & 240 & 298 & 384 & 389 & 1163 & 166 \\
\hline $\mathrm{Sr}$ & 381 & 340 & 83 & 57 & 138 & 36 & 36 & 414 & 31 \\
\hline $\mathrm{Rb}$ & 80 & 68 & 63 & 126 & 165 & 186 & 171 & 74 & 167 \\
\hline $\mathrm{Hf}$ & 7.2 & 6.9 & .43 & 2.3 & 2.6 & 1.9 & 2.1 & 1.88 & 1.91 \\
\hline $\mathrm{Ga}$ & 24 & 18 & 18 & 15 & 20 & 22 & 21 & 26 & 20 \\
\hline $\mathrm{Cr}$ & 56 & 40 & 5 & 42 & 49 & 50 & 50 & 5 & 42 \\
\hline $\mathrm{Ni}$ & 26 & 24 & 15 & 26 & 23 & 32 & 23 & 13 & 21 \\
\hline $\mathrm{Zr}$ & 216 & 176 & 82 & 73 & 75 & 77 & 72 & 368 & 57 \\
\hline $\mathrm{Nb}$ & 12 & 11 & 9 & 10 & 16 & 15 & 16 & 5 & 17 \\
\hline $\mathrm{Y}$ & 60 & 59 & 62 & 80 & 72 & 76 & 70 & 71 & 69 \\
\hline $\mathrm{Cu}$ & 7 & 8 & 53 & 7 & 7 & 11 & 22 & 19 & 6 \\
\hline $\mathrm{Zn}$ & 76 & 63 & 77 & 20 & 23 & 8 & $<5$ & 81 & 30 \\
\hline $\mathrm{Pb}$ & 20 & $<10$ & $<10$ & 16 & 15 & $<10$ & 17 & 12 & 26 \\
\hline Th & $<10$ & $<10$ & $<10$ & 16 & 16 & 21 & 19 & $<10$ & 14 \\
\hline $\mathrm{K} / \mathrm{Rb}$ & 349.15 & 404.65 & 333.84 & 304.15 & 219.66 & 205.14 & 221.68 & 363.97 & 229.48 \\
\hline $\mathrm{Rb} / \mathrm{Sr}$ & 0.21 & 0.20 & 0.76 & 2.21 & 1.20 & 5.17 & 4.75 & 0.18 & 5.39 \\
\hline $\mathrm{Mg}^{\#}$ & 26.5 & 26.7 & 14.6 & 19.2 & 14.4 & 23.8 & 19.2 & 24.7 & 9.7 \\
\hline $\mathrm{FeO} * / \mathrm{MgO}$ & 2.8 & 2.8 & 5.9 & 4.2 & 5.9 & 3.2 & 4.2 & 3.0 & 9.3 \\
\hline $\mathrm{K}{ }_{2} \mathrm{O} / \mathrm{Na}_{2} \mathrm{O}$ & 0.5 & 0.5 & 0.6 & 0.8 & 0.7 & 0.8 & 0.8 & 0.4 & 0.8 \\
\hline $\mathrm{CaO} / \mathrm{Na}_{2} \mathrm{O}$ & 0.3 & 0.3 & 0.1 & 0.1 & 0.0 & 0.0 & 0.1 & 0.2 & 0.1 \\
\hline $\mathrm{Na}_{2} \mathrm{O}+\mathrm{K}_{2} \mathrm{O}$ & 10.2 & 9.9 & 7.0 & 10.2 & 10.2 & 10.0 & 10.3 & 11.3 & 10.1 \\
\hline $\mathrm{Al}_{2} \mathrm{O}_{3}+\mathrm{CaO}$ & 16.9 & 16.6 & 15.1 & 12.7 & 13.1 & 12.4 & 12.6 & 17.6 & 12.8 \\
\hline $\mathrm{T}_{\mathrm{Zr}}\left({ }^{\circ} \mathrm{C}\right)$ & 768 & 757 & 753 & 699 & 706 & 709 & 699 & 803 & 683 \\
\hline $\mathrm{T}_{\mathrm{ap}}\left({ }^{\circ} \mathrm{C}\right)$ & 905 & 903 & 914 & 790 & 857 & 736 & 752 & 890 & 716 \\
\hline
\end{tabular}

On the $\log \mathrm{Zr} / \mathrm{TiO}_{2}$ vs. $\mathrm{SiO}_{2}$ binary diagram (Winchester and Floyd, 1977), mostly all volcanic samples plot within the rhyodacite-dacite and rhyolite fields while the coherent volcanic sample plots in the sub-alkali basalt field (Fig. 11a). On the normative Q-ANOR classification diagram (Streckeisen and Le Maitre, 1979), the Younger Granite samples plot in the alkali feldspar granite field, except one sample (MR-63), which plots in the alkali feldspar syenite field (Fig. 11b). The studied Dokhan Volcanics, felsites, and Younger Granites have high content of total alkalis $\left(\mathrm{Na}_{2} \mathrm{O}+\mathrm{K}_{2} \mathrm{O}\right)$ up to 12.2 wt. \%, which most probably indicate a type of alkali metasomatism, in particular, Na-metasomatism. Therefore, this high alkali enrichment should have affected some alkalis-related geochemical features, such as the Alumina index.

On the A/CNK-A/NK alumina saturation diagram of Shand (1943), the Younger Granites and majority of ignimbrites are peralkaline $(\mathrm{A} / \mathrm{CNK}$ and $\mathrm{A} / \mathrm{NK}<1)$, whereas three samples of ignimbrites, felsites and agglomerates are distributed among peralkaline, metaluminous, and peraluminous fields (Fig. 11c). The studied rock units including the Younger Granite and Dokhan-type varieties are mostly plot within the field of high-K-calc-alkaline series (Fig. 11d), according to the $\mathrm{K}_{2} \mathrm{O}$ vs. $\mathrm{SiO}_{2}$ diagram (Peccerillo and Taylor, 1976).

In a series of diagrams designed by Whalen et al. (1987) to discriminate A-type granites (Fig. 12), the Younger Granites and the majority of samples from the Dokhan Volcanics and felsites in the Ghuzah area exhibit geochemical signatures of A-type granites. The major elements signatures comprise high contents of $\mathrm{SiO}_{2}$, total alkalis, $\mathrm{FeO} / \mathrm{MgO}$ and $\left(\mathrm{Na}_{2} \mathrm{O}+\mathrm{K}_{2} \mathrm{O}\right) / \mathrm{CaO}$, and comprise low $\mathrm{CaO}, \mathrm{MgO}$, and $\mathrm{Al}_{2} \mathrm{O}_{3}+\mathrm{CaO}(<15$ wt. \%) contents. 
Fig. 11: Geochemical classification diagrams using major/trace elements. (A) Binary Log $\mathrm{Zr} / \mathrm{TiO}_{2}$ vs. $\mathrm{SiO}_{2}$ diagram for volcanic rocks using normative data. (B) CIPW normative-based QANOR diagram for plutonic rocks. (C) Binary molecular $\left[\mathrm{Al}_{2} \mathrm{O}_{3} /\left(\mathrm{Na}_{2} \mathrm{O}+\mathrm{K}_{2} \mathrm{O}\right)\right]$ vs. molecular $\left[\mathrm{Al}_{2} \mathrm{O}_{3} /(\mathrm{CaO}+\right.$ $\mathrm{Na}_{2} \mathrm{O}+\mathrm{K}_{2} \mathrm{O}$ )] diagram. (D) $\mathrm{SiO}_{2}$ vs. $\mathrm{K}_{2} \mathrm{O}$ binary diagram to distinguish various series of tholeiitic, calc-alkaline and shoshonitic rocks.
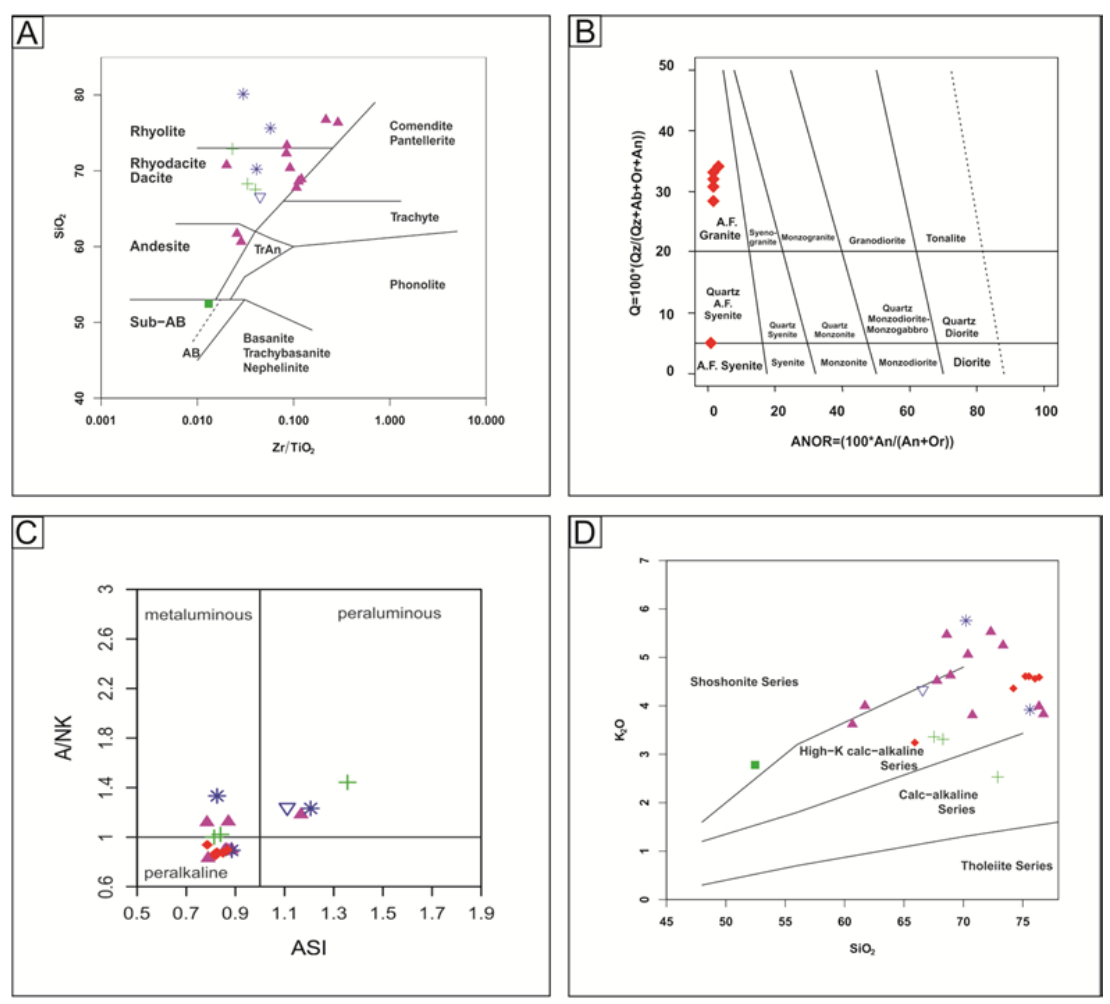
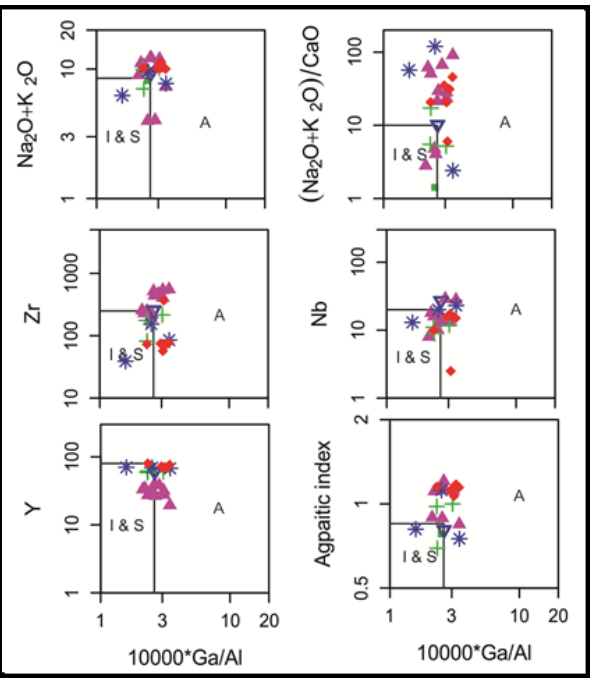

Fig. 12: Binary plots of $10000 * \mathrm{Ga} / \mathrm{Al}$ vs. $\left(\mathrm{Na}_{2} \mathrm{O}+\mathrm{K}_{2} \mathrm{O}\right),\left(\mathrm{Na}_{2} \mathrm{O}+\mathrm{K}_{2} \mathrm{O}\right) / \mathrm{CaO}, \mathrm{Zr}, \mathrm{Nb}, \mathrm{Y}$, Agpaitic index serving for the distinction of Atype granitoid rocks after Whalen et al. (1987).

The spider diagram normalized to primitive mantle values of Sun and McDonough (1989) shows that the investigated Dokhan Volcanics and felsites are characterized by an enrichment of LILE and relative depletion of HFSE (Fig. 13a). The diagram shows Rb, Ba, Th, U, Pb, and $\mathrm{Nb}$ enrichment and negative $\mathrm{Nb}$, Sr, and $\mathrm{P}$ anomalies compared to the primitive mantle. All the investigated samples, except the coherent volcanics, are characterized by negative Ti anomalies. The normalized pattern of the studied Younger Granite samples (Fig. 13b) shows Rb, Th, Ta, Nb, and Zr enrichment and Sr, P and Ti depletion. Such depletion is most likely related to the fractionation of plagioclase, apatite, and mafic minerals.

\section{TECTONIC SETTING}

On the $\mathrm{SiO}_{2}$ vs. $\mathrm{Al}_{2} \mathrm{O}_{3}$ geotectonic classification of granitoids proposed by Maniar and Piccoli (1989), the Younger Granites and most of volcanic samples plot within the post-orogenic granite field (Fig. 14a). On the $\mathrm{Y}+\mathrm{Nb}$ vs Rb tectonic discrimination diagram of Pearce et al. (1984), all Younger Granites, felsites, and Dokhan Volcanics plot in the within plate granite field (WPG), except ignimbrites, which occupy the area adjacent the volcanic arc and within plate granite field (Fig. 14b). All analyzed samples fall within the field of the post-collision granites (Pearce, 1996). This conclusion of post-collision tectonic setting confirms that the analyzed samples exhibit A-type geochemical characteristics and were generated in post-collision tectonic setting. The A-type setting of the studied samples is confirmed by the plotting of data in the field of the A-type granite in the I, S and A-type granitoids binary diagrams (Fig. 12) of Whalen et al. (1987). To get more characterization about the 
El-Gameel, et al.

A-type granite, two diagrams designated Eby (1992) were used (Figs. 15a and b). The two diagrams, including the binary diagram of $\mathrm{Y} / \mathrm{Nb}$ vs $\mathrm{Rb} / \mathrm{Nb}$, and the ternary diagram of $\mathrm{Nb}-\mathrm{Y}-\mathrm{Ga} * 3$, illustrated that the younger granites and the Dokhan-type varieties are of A2 type that formed in post-collisional setting.
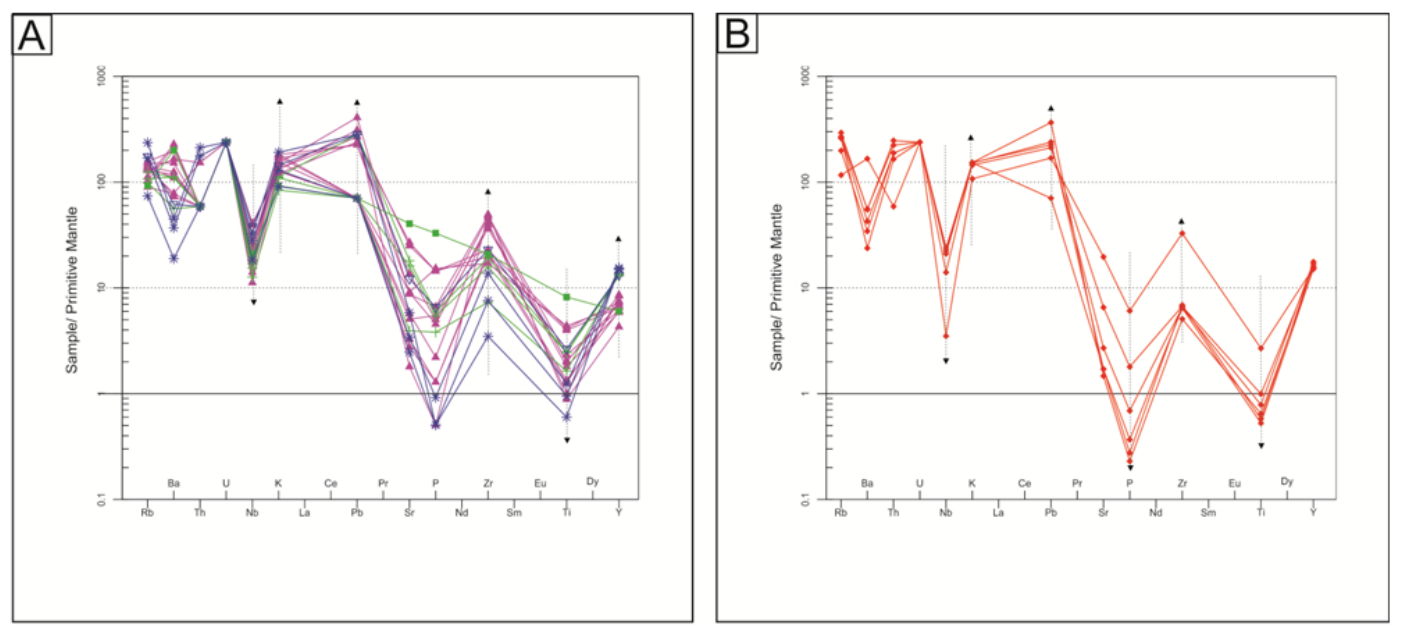

Fig. 13: (A) Trace element abundances of Wadi El-Ghuzah Dokhan-type volcanics normalized to primitive mantle values after Sun and McDonough (1989). (B) Trace element abundances of Wadi ElGhuzah Younger Granites normalized to primitive mantle values after Sun and McDonough (1989).

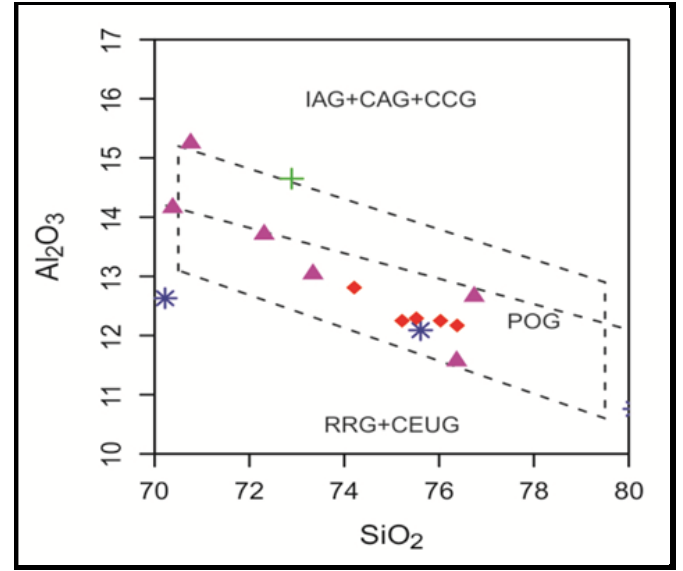

$\mathrm{A}$

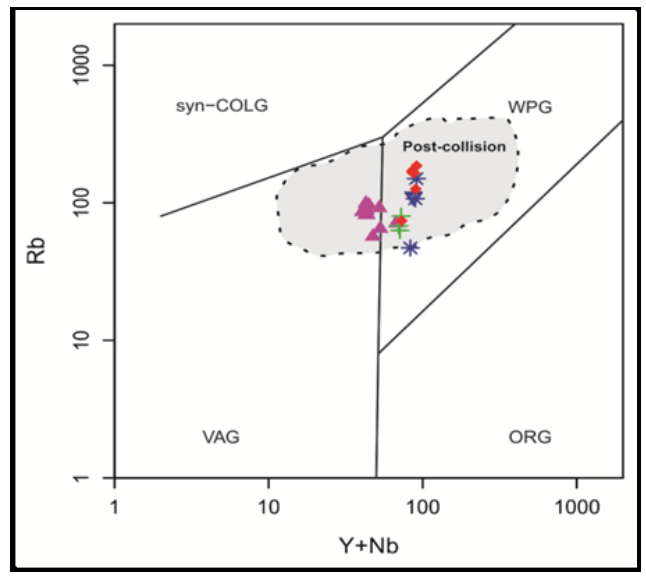

B

Fig. 14: (A) $\mathrm{SiO}_{2}$ vs. $\mathrm{Al}_{2} \mathrm{O}_{3}$ geotectonic classification of Younger granites (Maniar and Piccoli, 1989). (B) $\log (\mathrm{Y}+\mathrm{Nb}) v s . \log \mathrm{Rb}$ geotectonic classification of granites by Pearce et al. (1984).

\section{PETROGENESIS}

High-K calc-alkaline A-type magmas in post-collisional settings have been assumed to be generated by melting of crustal source rocks because of decompression following delamination of the lithospheric root and slab breakoff (e.g., Ali et al., 2013; Davies and von Blanckenburg, 1995; ElBialy, 2010; Eliwa et al., 2014; Moghazi, 2003; Schott and Schmeling, 1998; Sperner et al., 2001). Since many high-K calc-alkaline A-type granites in the Eastern Desert and Sinai are suggested to have evolved in a transitional post-collisional setting from compression to extension by melting of crustal rocks as a consequence of lithospheric delamination and slab breakoff (e.g., Azer, 2013; El-Bialy and Streck, 2009; Eliwa et al., 2014; Eyal et al., 2010; Farahat et al., 2011; Katzir et al., 2007; Moghazi et al., 1999; Moussa et al., 2008), melting of crustal materials is the most expected source for the generation of the Wadi El-Ghuzah post-collisional Younger Granites.

Three models for the derivation of the A-type granites, especially peraluminous from a crustal protolith are possible:-

1. Melting of metapelite and metagreywacke, including cases of basalt magma admixture (Sylvester, 1998; Koester et al., 2002; Eyal et al., 2004; Anderson and Morrison, 2005; Villaseca et al., 2008).

2. Partial melting of tonalites and granodiorites at a pressures of $8 \mathrm{kbar}$ with amphibole or pyroxene in restite (Skjerlie and Johnston, 1993; Patiño Douce, 1997). 


\section{Petrological characterization and remote sensing-based mapping}

3. Evolution of quite primitive low-Ca metaluminous granites by fractionation of amphibole (Bonin et al., 1998; Amer et al., 2010; Chappell et al., 2012).
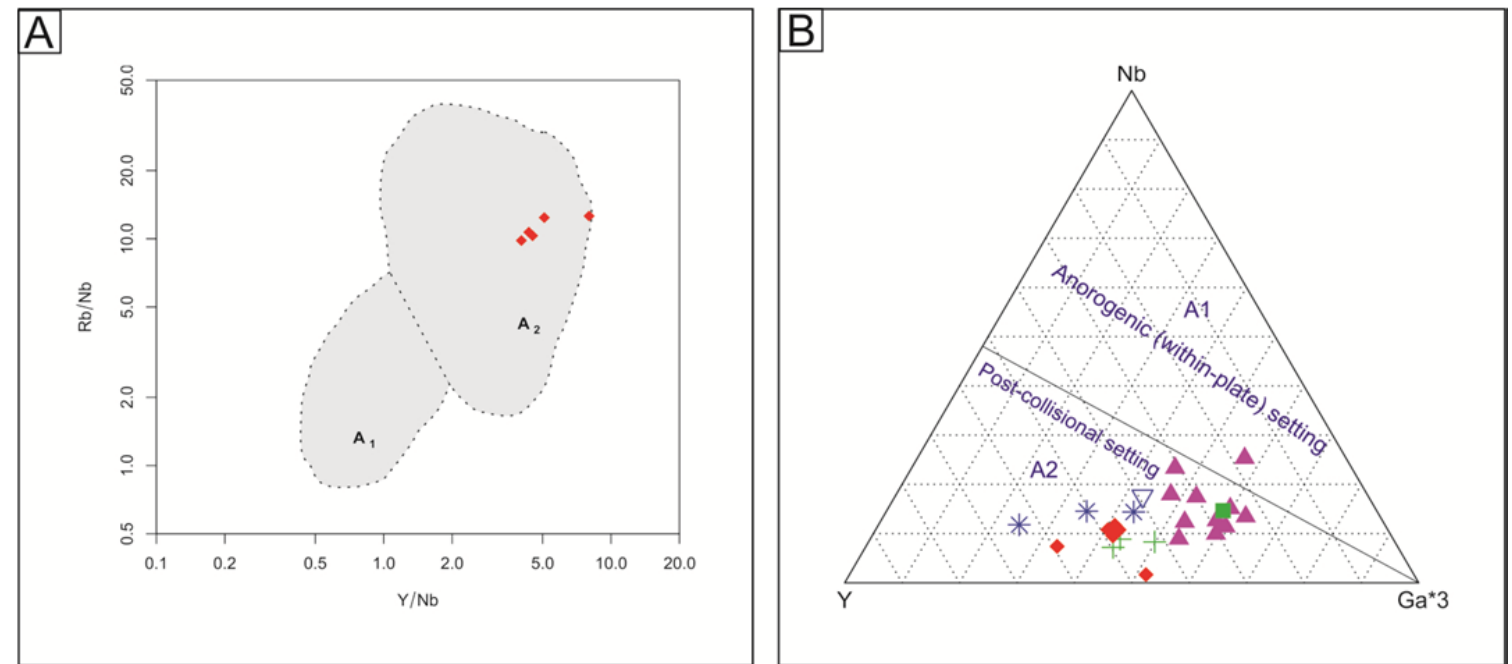

Fig. 15: (A and B) the diagrams for A-type granites from (Eby, 1992). (A) The binary $\mathrm{Y} / \mathrm{Nb}$ vs. Rb/Nb diagram. (B) The ternary Nb-Y-Ga*3 diagram. A1: field for anorogenic A-type granites, A2: field for postcollisional A-type granites.

Using the petrogenesis discrimination diagram of Gerdes et al. (2000), the Younger Granites and Dokhan Volcanics plot mostly in the fields of felsic metapelites and greywackes (Fig. 16a). Taking in consideration the excess enrichment of alkalis in the studied Younger Granite and Dokhan Volcanics due to the metasomatic action, the matter that gives a chance for doubt about the metapelitic origin of these rocks. Moreover, the almost absence of the metapelitic rocks in the study and nearby areas. This was a strong motivated reason to look for another petrogenetic model.

Using the petrogenesis diagram of Laurent (2014), the studied Younger Granites and Dokhan Volcanics plot mostly in the tonalite field (Fig. 16b). It means that these rocks seem to have been derived by partial melting of tonalite. This model makes more sense, despite of plotting two ignimbrite samples out of twelve in the field of metasediments but it could refer to the enrichment of alkalis because of metasomatism. Therefore, the studied rocks seem to be derived from the partial melting of tonalite-granodiorite rather than the partial melting of metapelites. This assumption is supported by the abundance of tonalite-granodiorite and lack of metapelitic rocks in the study area. Furthermore, this conclusion is consistent with the classification of Eby (1992) in which the A-type granites is subdivided into A1 and A2 groups. The A1 group is mantle-derived emplaced in an anorogenic setting; while the A2 group is a crustal derived magma of a post-orogenic setting. Therefore, the studied rocks are belonging to the A2 group of A-type granite.

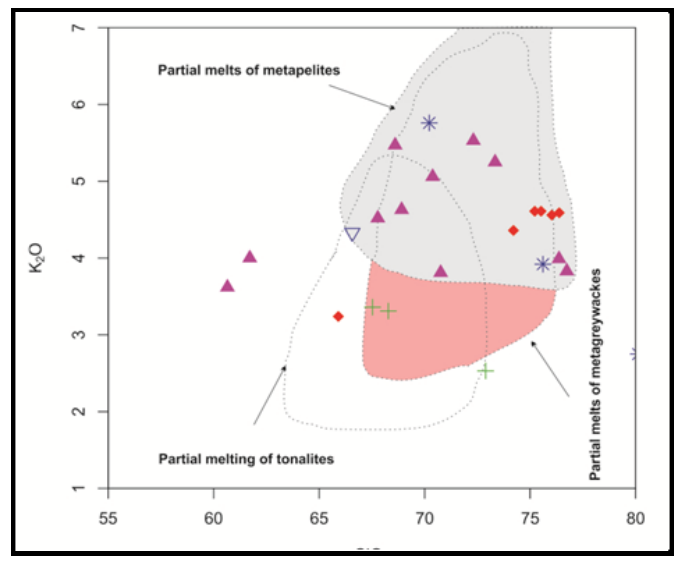

$\mathrm{a}$

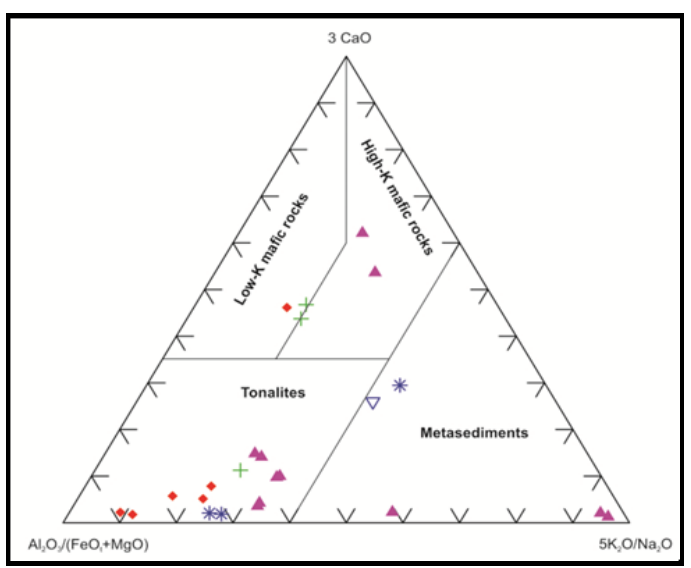

b

Fig. 16: (a) Composition of the Wadi El-Ghuzah Younger Granites, Felsite and Dokhan-type volcanics compared to melts produced by experimental dehydration melting of metasedimentary and igneous rocks. Fields of melt compositions in (a) are after Gerdes et al. (2000). (b) Ternary diagram $\mathrm{Al}_{2} \mathrm{O}_{3} /\left(\mathrm{FeO}_{\mathrm{t}}+\mathrm{MgO}\right) ; 3 * \mathrm{CaO} ; 5$ * $\left(\mathrm{K}_{2} \mathrm{O} / \mathrm{Na}_{2} \mathrm{O}\right)$ representing the composition of melts derived from a range of potential sources (tonalites, metasediments, low- and high-K mafic rocks). 


\section{El-Gameel, et al.}

\section{CONCLUSION}

Late Neoproterozoic rocks are mainly represented in Wadi El Ghuza area by the Hammamat sedimentary rocks, Dokhan volcanics, felsite intrusions and younger granite rocks dissected by a series of post-granitic dykes. This research introduces a new detailed insight into the geology of Wadi El Ghuza area. The examination of the volcanosedimentary succession was a challenging task because of its very high relief and tough topography. Wadi El Ghuza area is one of the typical localities of volcanosedimentary successions in the North Eastern Desert with intercalating Hammamat sedimentary rocks and Dokhan volcanics. A generalized lithostratigraphic profile of these rocks was constructed, for the first time, based on the compilation of six consecutive profiles measured during detailed fieldwork along the outcrops of the volcanosedimentary successions. Detailed petrological study of the volcanosedimentary rocks indicate that the succession comprises pyroclastics and agglomerates of Dokhan volcanics intercalated with sandstones and siltstones of Hammamat rocks.

The remote sensing-based geological mapping represents a pioneer contribution to the geology of Wadi El Ghuza area. The technique allowed overcoming the mapping challenges arisen from the large mapping area and the various rock units with complex field relationships. The performed image enhancement techniques proved that the ASTER and ETM+ data are useful for regional lithological mapping. The false color composite of 157 in RGB derived by applying the optimum index factor on ETM+ data and the composite of 421 in RGB derived from ASTER principal component analysis technique allowed the discrimination between the different rock units in Wadi El Ghuza area. These techniques are likely suitable for mapping similar lithologies elsewhere in the Precambrian basement rocks in Egypt.

Geochemical studies of Late Neoproterozoic units, including the Dokhan volcanics and the Younger Granites, indicate that they are of high-K calc-alkaline affinity and were produced from Atype magmas in post-collisional settings. The studied A-type magma have been assumed to be generated by melting of crustal rocks of tonalite composition.

\section{REFERENCES}

Ali, K. A., Wilde, S. A., Stern, R. J., Moghazi, A. K. M., and Ameen, S. M. (2013): Hf isotopic composition of single zircons from Neoproterozoic arc volcanics and post-collision granites, Eastern Desert of Egypt: Implications for crustal growth and recycling in the Arabian-Nubian Shield. Precamb. Res, 239, 42-55.

Amer, R., Kusky, T., and Ghulam, A. (2010): Lithological mapping in the Central Eastern Desert of Egypt using ASTER data. J. Afr. Earth Sci, 56(2-3): 75-82.

Anderson, J. L., and Morrison, J. (2005): Ilmenite, magnetite, and peraluminous Mesoproterozoic anorogenic granites of Laurentia and Baltica. Lithos, 80(1-4), 45-60.

Azer, M. K. (2013): Late Ediacaran (605-580 Ma) post-collisional alkaline magmatism in the Arabian-Nubian Shield: a case study of Serbal ring-shaped intrusion, southern Sinai, Egypt. J. Asi. Earth Sci, 77, 203-223.

Bonin, B., Azzouni-Sekkal, A., Bussy, F., and Ferrag, S. (1998): Alkali-calcic and alkaline postorogenic (PO) granite magmatism: petrologic constraints and geodynamic settings. Lithos, 45(1-4), 45-70.

Chappell, B. W., Bryant, C. J., and Wyborn, D. (2012): Peraluminous I-type granites. Lithos, 153, 142-153.

Chavez, P. (1984): Image Processing techniques for Thermatic Mapper data. Proceedings, ASPRSACSM Technical Papers, 2, 728-742.

Chavez, P., Berlin, G. L., and Sowers, L. B. (1982): Statistical method for selecting landsat MSS. J Appl Photogr Eng, 8(1), 23-30.

Cox, K., Bell, J., and Pankhurst, R. (1979): The interpretation of igneous rocks. London, Allen: Unwin.

Davies, J. H., and von Blanckenburg, F. (1995): Slab breakoff: a model of lithosphere detachment and its test in the magmatism and deformation of collisional orogens. Earth Planet Sci. Lett., 129(1-4), 85-102.

Eby, G. N. (1992): Chemical subdivision of the A-type granitoids: petrogenetic and tectonic implications. Geology, 20(7), 641-644. 
El-Bialy, M. Z. (2010): On the Pan-African transition of the Arabian-Nubian Shield from compression to extension: the post-collision Dokhan volcanic suite of Kid-Malhak region, Sinai, Egypt. Gondwana Res., 17(1), 26-43.

El-Bialy, M. Z., and Streck, M. J. (2009): Late Neoproterozoic alkaline magmatism in the ArabianNubian Shield: the postcollisional A-type granite of Sahara-Umm Adawi pluton, Sinai, Egypt. Arab. J. Geosci., 2(2), 151-174.

El-Gaby, S., List, F., and Tehrani, R. (1990): The basement complex of the Eastern Desert and Sinai, In: Said R. (ed): The geology of Egypt AA Balkema, Rotterdam/Brookfield, 734: 175-184.

El-Gameel, K. (2018): The Ediacaran volcanosedimentary succession of Gabal Abu Had, North Eastern Desert, Egypt: geological study, facies analyses, and depositional setting. Arab. J. Geosci., 11(8): 185.

Eliwa, H. A., El-Bialy, M. Z., and Murata, M. (2014): Edicaran post-collisional volcanism in the Arabian-Nubian Shield: The high-K calc-alkaline Dokhan Volcanics of Gabal Samr El-Qaa (592 \pm 5 Ma), North Eastern Desert, Egypt. Precambrian Res., 246, 180-207.

Eyal, M., Litvinovsky, B., Jahn, B., Zanvilevich, A., and Katzir, Y. (2010): Origin and evolution of post-collisional magmatism: coeval Neoproterozoic calc-alkaline and alkaline suites of the Sinai Peninsula. Chem. Geol., 269(3-4), 153-179.

Eyal, M., Litvinovsky, B., Katzir, Y., and Zanvilevich, A. (2004): The Pan-African high-K calcalkaline peraluminous Elat granite from southern Israel: geology, geochemistry and petrogenesis. J. Afr. Earth Sci, 40(3-4), 115-136.

Farahat, E. S., Zaki, R., Hauzenberger, C., and Sami, M. (2011): Neoproterozoic calc-alkaline peraluminous granitoids of the Deleihimmi pluton, Central Eastern Desert, Egypt: implications for transition from late-to post-collisional tectonomagmatic evolution in the northern Arabian-Nubian Shield. Geol. J., 46(6), 544-560.

Gerdes, A., Wörner, G., and Henk, A. (2000): Post-collisional granite generation and HT-LP metamorphism by radiogenic heating: the Variscan South Bohemian Batholith. J. Geol. Soc., 157(3), 577-587.

Gomez, C., Delacourt, C., Allemand, P., Ledru, P., and Wackerle, R. (2005): Using ASTER remote sensing data set for geological mapping, in Namibia. PCEC, Parts A/B/C, 30(1-3): 97-108.

Hashim, M., Ahmad, S., Johari, M. A. M., and Pour, A. B. (2013): Automatic lineament extraction in a heavily vegetated region using Landsat Enhanced Thematic Mapper (ETM+) imagery. AdSpR, 51(5): 874-890.

Hassan, M. A., and Hashad, A. H. (1990): Precambrian of Egypt. In: Said, R (ed): The geology of Egypt Balkema, Rotterdam: 201-245.

Irvine, T., and Baragar, W. (1971): A guide to the chemical classification of the common volcanic rocks. CaJES, 8(5): 523-548.

Katzir, Y., Eyal, M., Litvinovsky, B., Jahn, B., Zanvilevich, A., Valley, J., Shimshilashvili, E. (2007): Petrogenesis of A-type granites and origin of vertical zoning in the Katharina pluton, Gebel Mussa (Mt. Moses) area, Sinai, Egypt. Lithos, 95(3-4): 208-228.

Koester, E., Pawley, A. R., Fernandes, L. A., Porcher, C. C., and Soliani Jr, E. (2002): Experimental melting of cordierite gneiss and the petrogenesis of syntranscurrent peraluminous granites in southern Brazil. J. Petr., 43(8): 1595-1616.

Laurent, O., Martin, H., Moyen, J.-F., and Doucelance, R. (2014): The diversity and evolution of lateArchean granitoids: Evidence for the onset of "modern-style" plate tectonics between 3.0 and 2.5 Ga. Lithos, 205: 208-235.

Le Bas, M., LE Maitre, R., Streckeisen, A., Zanettin, B., and Rocks, I. S. o. t. S. o. I. (1986): A chemical classification of volcanic rocks based on the total alkali-silica diagram. J. Petr., 27(3), 745-750.

Loughlin, W. (1991): Principal component analysis for alteration mapping. Photogramm Eng. Rem. S., 57(9): 1163-1169.

Maniar, P. D., and Piccoli, P. M. (1989). Tectonic discrimination of granitoids. Geol. Soc. Am. Bull., 101(5): 635-643.

Middlemost, E. A. (2014): Magmas, rocks and planetary development: a survey of magma/igneous rock systems: Routledge.

Moghazi, A. (2003): Geochemistry and petrogenesis of a high-K calc-alkaline Dokhan Volcanic suite, South Safaga area, Egypt: the role of late Neoproterozoic crustal extension. Precamb. Res., 125(1), 161-178. 
El-Gameel, et al.

Moghazi, A., Mohamed, F., and Kanisawa, S. (1999): Geochemical and petrological evidence of calcalkaline and A-type magmatism in the Homrit Waggat and El-Yatima areas of eastern Egypt. J. Afr. Earth Sci, 29(3): 535-549.

Moussa, E. M., Stern, R. J., Manton, W. I., and Ali, K. A. (2008): SHRIMP zircon dating and Sm/Nd isotopic investigations of Neoproterozoic granitoids, Eastern Desert, Egypt. Precamb. Res., 160(34): 341-356.

Patiño Douce, A. E. (1997): Generation of metaluminous A-type granites by low-pressure melting of calc-alkaline granitoids. Geology, 25(8): 743-746.

Pearce, J. A. (1996): A user's guide to basalt discrimination diagrams. Trace element geochemistry of volcanic rocks: applications for massive sulphide exploration. Geol. Assoc. Can., Short Course Notes, 12: 79-113.

Pearce, J. A., Harris, N. B., and Tindle, A. G. (1984): Trace element discrimination diagrams for the tectonic interpretation of granitic rocks. J. Petr., 25(4): 956-983.

Peccerillo, A., and Taylor, S. (1976): Geochemistry of Eocene calc-alkaline volcanic rocks from the Kastamonu area, northern Turkey. Contrib. Mineral. Petr., 58(1), 63-81.

Sabins, F. F. (2007): Remote sensing: principles and applications, $3^{\text {rd }}$ ed: Waveland Press Inc.

Schott, B., and Schmeling, H. (1998): Delamination and detachment of a lithospheric root. Tectonophysics, 296(3-4): 225-247.

Shand, S. J. (1943): Eruptive rocks: their genesis, composition, classification, and their relation to oredeposits, with a chapter on meteorites: John Wiley and Sons, New York.

Skjerlie, K. P., and Johnston, A. D. (1993): Fluid-absent melting behavior of an F-rich tonalitic gneiss at mid-crustal pressures: implications for the generation of anorogenic granites. J. Petr., 34(4), 785815.

Sperner, B., Lorenz, F., Bonjer, K., Hettel, S., Müller, B., and Wenzel, F. (2001): Slab break-offabrupt cut or gradual detachment? New insights from the Vrancea Region (SE Carpathians, Romania). Terra Nova, 13(3): 172-179.

Stern, R. J. (1994): Arc assembly and continental collision in the Neoproterozoic East African Orogen: implications for the consolidation of Gondwanaland. Annu. Rev. Earth. Planet. Sci., 22(1): 319351.

Stern, R. J., Johnson, P. R., Kröner, A., and Yibas, B. (2004): Neoproterozoic ophiolites of the Arabian-Nubian shield. Dev. Prec. Geol., 13: 95-128.

Streckeisen, A., and Le Maitre, R. (1979): A chemical approximation to the modal QAPF classification of the igneous rocks. NJM, Abhandlungen, 136: 169-206.

Subramanian, P., Alamelu, N. R., and Aramudhan, M. (2006): Fusion of multispectral and panchromatic images and its quality assessment. ARPN J. of Eng. and Appl Sci., 9(10), 4126-4132.

Sun, S.-S., and McDonough, W. F. (1989): Chemical and isotopic systematics of oceanic basalts: implications for mantle composition and processes. Geol. Soc. London, Sp. Publ., 42(1): 313-345.

Sylvester, P. J. (1998): Post-collisional strongly peraluminous granites. Lithos, 45(1-4), 29-44.

Villaseca, C., Perez-Soba, C., Merino, E. M., Orejana, D., Lopez-Garcia, J. A., and Billstrom, K. (2008): Contrasted crustal sources for peraluminous granites of the segmented Montes de Toledo Batholith (Iberian Variscan Belt). J. Geosci., 53(3-4): 263-280.

Whalen, J. B., Currie, K. L., and Chappell, B. W. (1987): A-type granites: geochemical characteristics, discrimination and petrogenesis. Contrib. Mineral. Petr., 95(4), 407-419.

Winchester, J. A., and Floyd, P. A. (1977): Geochemical discrimination of different magma series and their differentiation products using immobile elements. Chem. Geol., 20, 325-343.

Yakhdani, M. F., and Azizi, A. (2010): Quality assessment of image fusion techniques for multisensor high resolution satellite images (case study: IRS-P5 and IRS-P6 satellite images). In W. W., and B. Székely (Eds.), Isprs TC VII symposium-100 years ISPRS (pp. Part 7B). Vienna, Austria.

Yamaguchi, Y., and Naito, C. (2003): Spectral indices for lithologic discrimination and mapping by using the ASTER SWIR bands. Int. J. Remote. Sens., 24(22), 4311-4323. 
Petrological characterization and remote sensing-based mapping

الخواص البترولوجية والتخريط الجيولوجي المستثد على الاستشعار عن بعد لمنطقة وادي الغزاة ، شمال الصحراء الثرقية ، مصر الشع

خالد الجمبل و حسن عليوة و محمد عبد الرشيد و حمدي الدسوقي

قسم الجيولوجيا - كلية العلوم - جامعة المنوفية

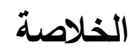

تقع منطقة وادي الغزاة شمال طريق سفاجا - قنا الأسفلتي وتغطى مساحة حوالي .0 كـ كمّ، و بهيمن عليها وحدات

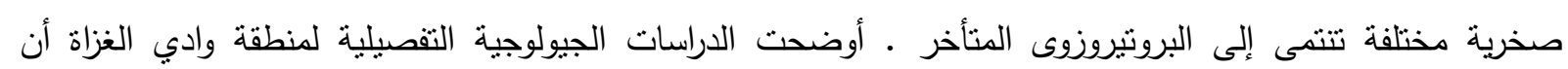
المنطقة تضم وحدات من صخور بركانية متحولة وسربنتين وجابرو متحول وجرانيتات قديمة وتتابعات بركانية رسوبية

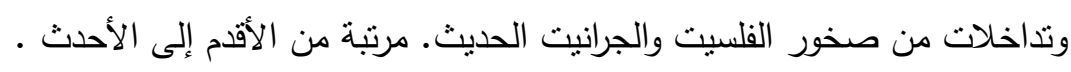

تم قياس ستة قطاعات متتالية للمرة الأولى في تتابعات الصخور البركانية والرسوبية بمنطقة وادي الغزاة ، واوضحت

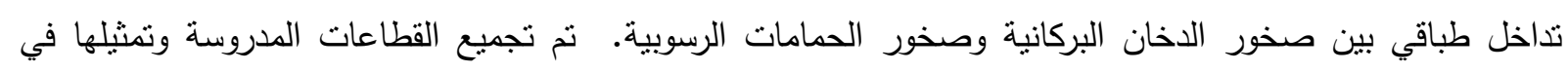
قطاع واحد يعبر عن كامل نتابع الصخور البركانية والرسوبية في المنطقة.

نم إعداد خريطة جيولوجية تقصيلية جديدة للمنطقة باستخدام تقنيات الاستشعار عن بعد والعمل الميداني التقليدي و

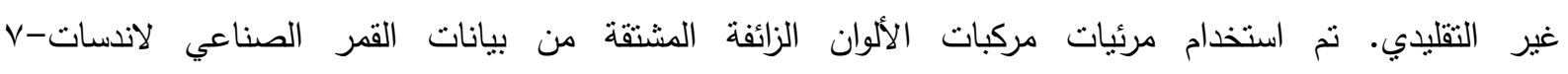
بالإضافة إلى مرئيات المكونات الأساسية المشتقة من بيانات القمر الصناعي أستر لئنة للتمييز بين الوحدات الصخرية المختلفة في منطقة الدراسة. تثنير الدراسات الجيوكيميائية لصخور الدخان البركانية وصخور الجرانيت الحديث انها ذات نقارب عالي من القلويات

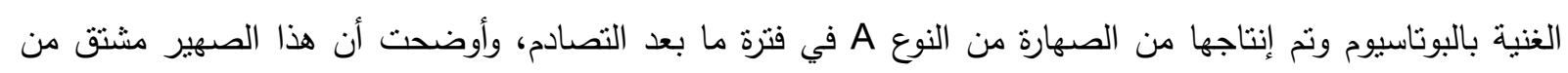
الإذابة الجزئية لصخور القترة القارية ذات تكوين التوناليت. 